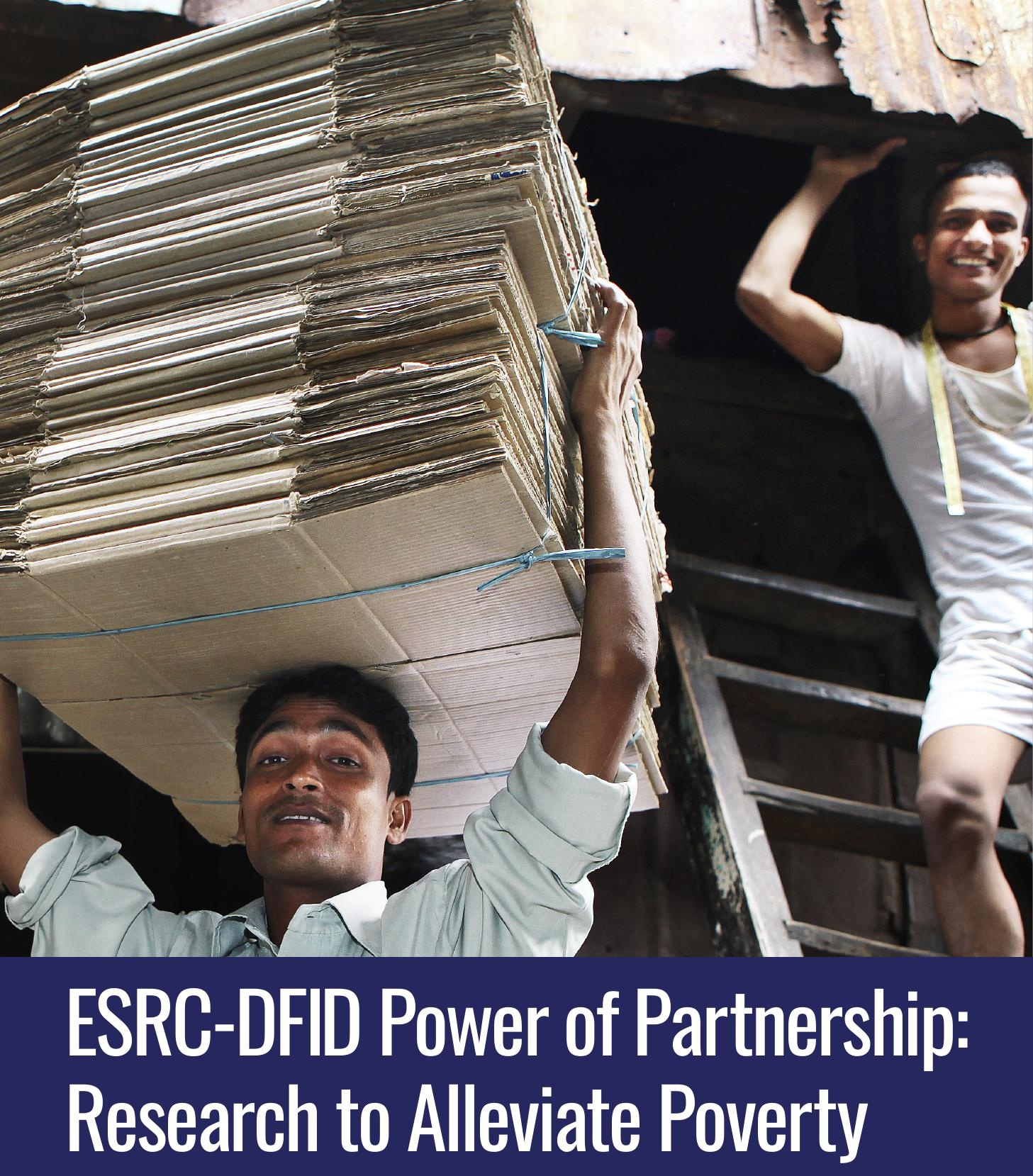

$\mathrm{E} \cdot \mathrm{S} \cdot \mathrm{R} \cdot \mathrm{C}$ ECONOMIC \& SOCIAL RESEARCH C OUNCI L

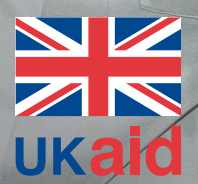

Research jointly supported by the ESRC and DFID
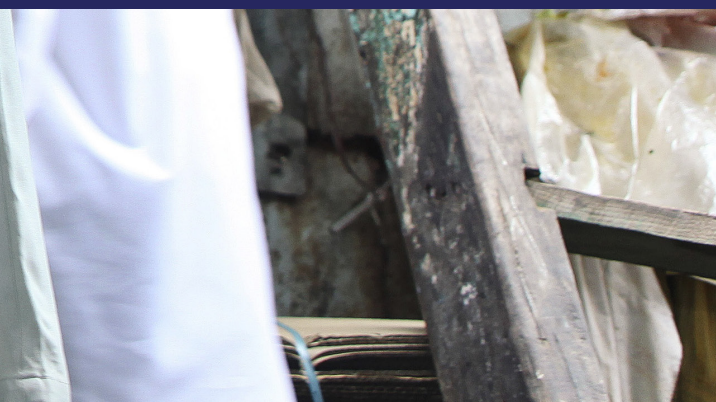
This booklet was prepared for a three-day event entitled

'Power of Partnership: Research to Alleviate Poverty,

hosted by the ESRC-DFID Strategic Partnership, which

took place in New Delhi, India from 3 to 5 December 2018.

Cover photo: India, Mumbai (Bombay), Maharashtra. Men transporting recycled cardboard. Dharavi has a waste recycling industry that is helping thousands of slum dwellers out of poverty. The recycling of the discarded waste of Mumbai's 19 million citizens is a thriving business propelled by thousands of microentrepreneurs.

Economists estimate that the output of the slum is over US $\$ 1$ billion a year.

(C) Dieter Telemans/Panos 


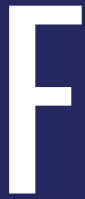

ormed in August 2005, the UK's Economic and Social Research Council (ESRC) and the Department for International Development (DFID) Strategic Partnership funds worldclass scientific research on a broad range of topics. The partnership contributes to a robust conceptual and empirical basis for development, but it also provides a space to build a collective understanding and develop new knowledge on some of the world's most complex challenges.

\section{Power of Partnership: Research to Alleviate Poverty} focuses on the ESRC-DFID Joint Fund for Poverty Alleviation Research as it approaches its final phase. This activity is designed to capture learning from the Fund, help secure its legacy, and support grant holders to maximise the impact of their research.

As an event intended to link academics to policy makers and practitioners, great attention has been given to shape an agenda that provides both learning and knowledge exchange opportunities for academic attendees and policy offers for the non-academic delegates. Themes, presentations and participatory sessions have been designed to leverage awareness of the research with key audiences, create new partnerships and relationships, and grow the capacity of delegates to contribute to evidenceinformed policy and practice.

This is more than a conference but a chance to reflect, forge new connections, and build a shared vision for the future of developmentrelated social science research.

\section{Catherine Flynn}

Programme Lead for ESRC-DFID Joint Fund for Poverty Alleviation Research Programme and Senior Research Portfolio Manager International Development

ESRC

\section{Dr Tim Conway}

Senior Social Development Advisor in DFID's Research and Evidence Division
(C) Giacomo Pirozzi/Panos

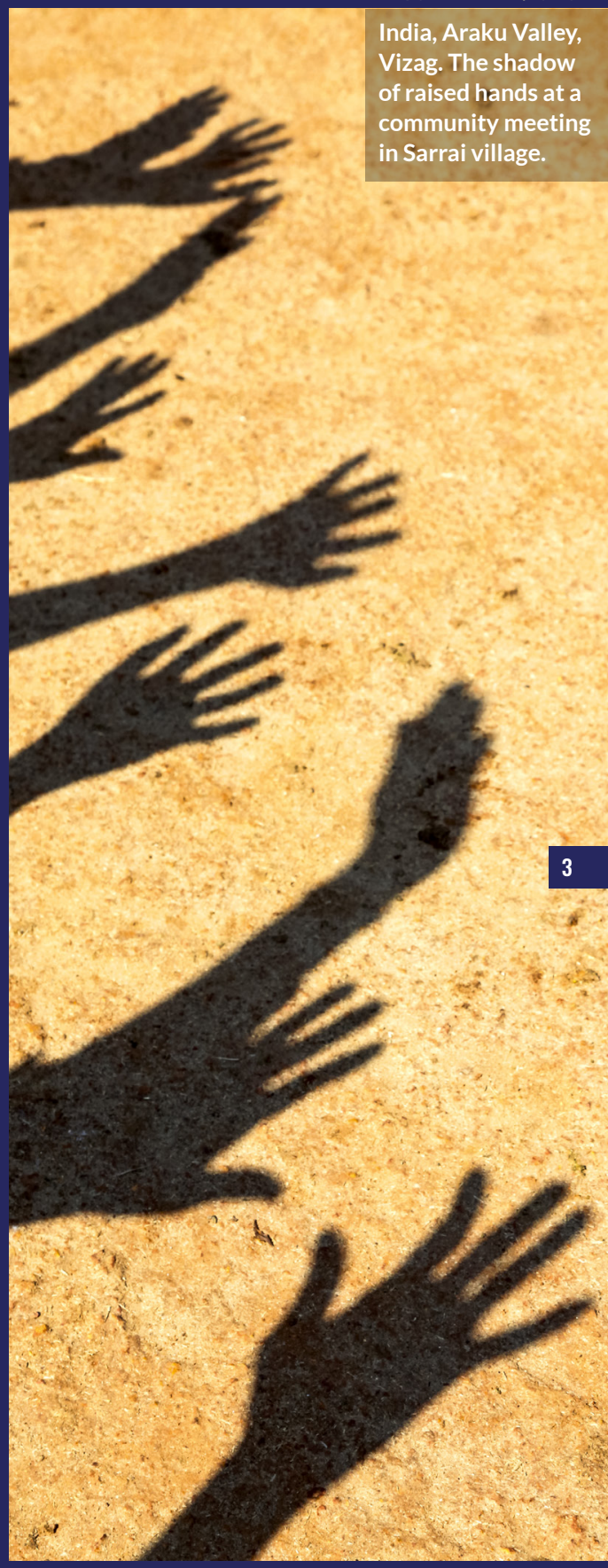




\section{Power of partnership and pathways out of poverty}

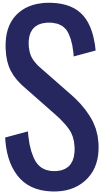
ince the ESRC-DFID Joint Fund for Poverty Alleviation Research was established in 2005, the world in which we work has changed significantly. Most countries have seen major gains in living standards and human development, with significant improvements in health and education outcomes. Yet these gains are often vulnerable to reversal; structural inequalities and harmful social norms persist. In the last decade, we have witnessed a crisis in the global economy and, after a period of sustained decline, a resurgence in the number and intensity of conflicts. Recent years have seen an upswing in violent deaths and forced displacement, the spread of populist politics, and closing space for civil society. While poverty continues to fall at a global scale, the rate of this decline is slowing as extreme poverty becomes increasingly concentrated in a smaller set of countries which face multiple and deep-rooted challenges, including social and political fragility, and armed conflict. Climate change and environmental degradation pose fundamental challenges to the sustainability of many development gains.

Traditional North-South development paradigms are giving way to a more interconnected, globalised, rapidly changing world that needs new kinds of action and relationships. Youth and social movements have seized political spaces and opportunities with varying degrees of success in an attempt to redefine notions of social and personal justice and freedom. In many countries, repressive governments have sought to suppress such opposition. Positive change requires new kinds of research and knowledge focused on how we can work together.

Over time, the Joint Fund also evolved; the initial focus on the MDGs diminished, and emphasis was placed on pathways out of poverty, institutional conditions that alleviate poverty and violence and insecurity. Meanwhile, taking a strategic approach to impact increased with the requirement of clear pathways to impact statements. There has always been an expectation that the diverse, world-class scientific research the scheme funds would have the potential for impact on policy and practice for poverty reduction. In this challenging context, the Joint Fund has been well-suited to respond to a growing requirement for new knowledge about the complex lives, experiences, and strategies of the poorest and most marginalised in society.

Pathways out of poverty and oppression are multiple and take many shapes. There is increasing recognition that poverty is multidimensional in nature, and that our analysis of wellbeing needs to consider not only material dimensions (low income and consumption, a lack of assets or services) but also social phenomena (shame, stigma, exclusion and violence) - and the mutuallyreinforcing relationships between material and social outcomes. Supporting journeys to more positive wellbeing and lives that are more livable requires acknowledging gendered and international power dynamics and social norms, as well as exclusionary behaviours and systems in communities and institutions. The negative effects of 
intersecting inequalities of race, ethnicity, caste, religion, sexuality, and physical and mental ability run deep in all of our societies.

ESRC-DFID's Joint Fund has supported $172^{1}$ geographically diverse research projects in which academics work in partnership with civil society, non-governmental, and governmental organisations. Projects cover multidimensional aspects of poverty and include issues such as inequality in education, health system reform, secure livelihoods, economic strategies and social protection, gender in everyday lives, and childhood and youth. Research has built understanding of how poor and marginalised people navigate and negotiate their futures, and has influenced policy contexts and broader transformational changes in societies. Since 2016, the Impact Initiative for International Development Research, working closely with ESRC-DFID, has been focused on strengthening linkages between groups of grantees and intermediaries, promoting critical bodies of knowledge and learning, addressing shared capacity issues, and evidencing impact. As the Fund completes its final phase, we are in a unique position to share learning from across this portfolio of evidence. This comprehensive guide provides practitioners and policy actors with an indispensable catalogue of cuttingedge research that has real implications for policy and programmes. The guide is being launched at a major international event, 'Power of Partnership', in Delhi, in December 2018.

This conference of academics, practitioners, knowledge brokers, policy actors, and donors from the international community will extend learning and ongoing innovation across regions and projects. Much of the research presented has been co-constructed and codelivered through innovative local and global partnerships committed to inclusivity and engagement with policy and practice.

${ }^{1}$ According to data available at the time of printing.
Learning across the Joint Fund includes interrogating what makes partnership successful in achieving impact in policy and practice and in making poor people's lives better. Questioning the interactions between research, politics, and practice includes addressing the politics of evidence; building capacity and interfaces between academics, knowledge brokers, and decisionmakers; and making new spaces for the voices of often excluded and marginalised populations to be heard. The research across the portfolio of ESRC-DFID's Joint Fund can contribute to leaving no one behind in meeting the SDGs in diverse cultural and political global contexts.

As Amartya Sen reminds us, 'justice is not indifferent to the lives that people can actually live' (The Idea of Justice, 2009: 18). We need to combine an understanding of human lives, experiences, and realisations alongside institutions and rules.

It is with respect that we can learn from all of the projects profiled here and discover new ways to challenge our assumptions, illuminate the complexity of poverty and social norms, and inform institutional dynamics as well as local, national, and international policy and practice. All of the projects listed in this booklet were enabled by the ESRC-DFID Joint Fund for Poverty Alleviation Research. It is intended to be a practical guide that will enable grant holders to be aware of and connect with each other's work. There is still a long journey towards the realisation of rights and equality, social and personal justice for poor and marginalised people. But better to build trust and to travel and learn together that is the power of partnership.

\section{Dr Vicky Johnson}

Goldsmiths, University of London and Honorary Associate of the Institute of Development Studies 


\section{ESRC-DFID Power of Partnership: Research to Alleviate Poverty}

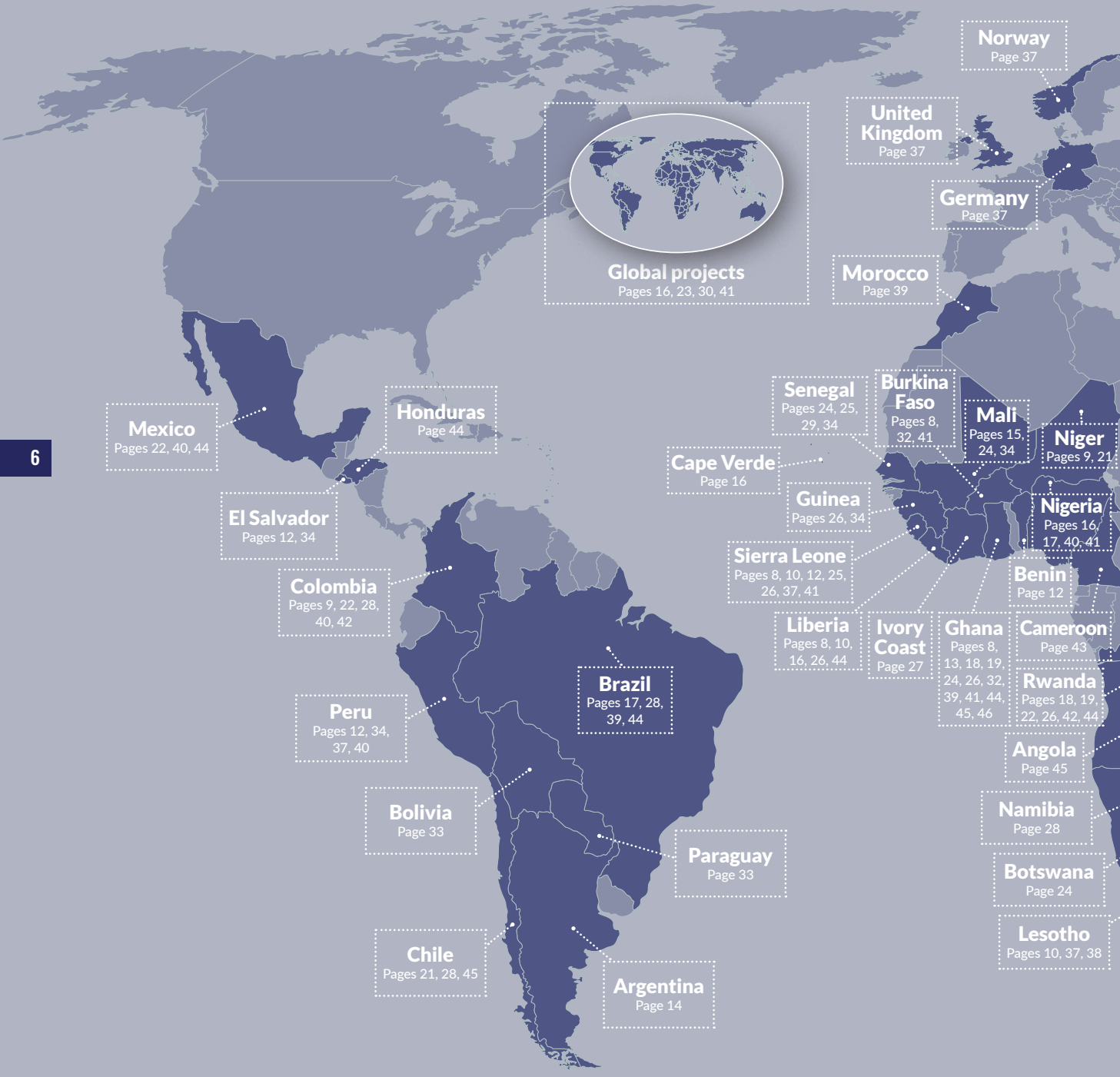


Research enabled through the UK's Economic and Social Research Council (ESRC) and the Department for International Development (DFID)'s Strategic Partnership from the Joint Fund for Poverty Alleviation Research, including projects featured in the 'Power of Partnership: Research to Alleviate Poverty' event hosted by ESRC-DFID in New Delhi, India from 3 to 5 December 2018.

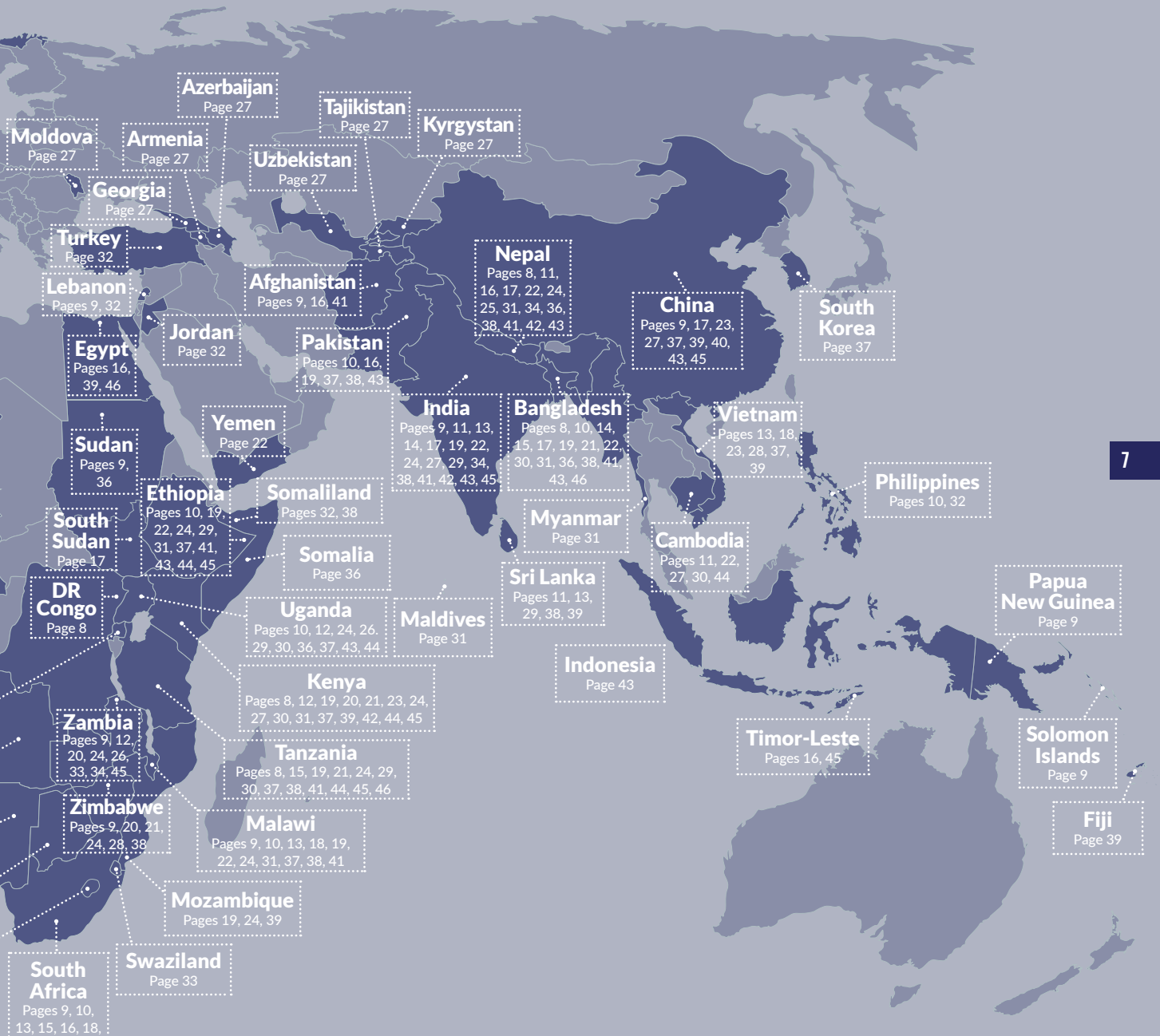




\section{Glossary of projects}

To explore the research and its policy and practice implications, or for more information about The Impact Initiative for International Development Research, visit: www.theimpactinitiative.net

The projects listed in this glossary were enabled by the ESRC-DFID Joint Fund for Poverty Alleviation Research which aims to enhance the quality and impact of social science research with the goal of reducing poverty amongst the poorest countries and peoples of the world. It includes the projects featured in the 'Power of Partnership: Research to Alleviate Poverty' event hosted by ESRC-DFID in New Delhi, India from 3 to 5 December 2018.

A behavioural economic analysis of reproductive health in Burkina Faso and Tanzania (Burkina Faso, Tanzania)

July 2016 - June 2019

Ben D'Exelle

UNIVERSITY OF EAST ANGLIA, UK

A cause of the inadequate uptake of reproductive health services is women's lack of control over pregnancy-related decisions. This research aims to generate new insights that explain the low or inadequate uptake of reproductive health services in Burkina Faso and Tanzania.

A comparative analysis of combatants' economic and social-political power during and after war (Democratic Republic of Congo, Liberia, Sierra Leone)

July 2015 - July 2018

Paul Nugent

UNIVERSITY OF EDINBURGH, UK

The linkages between poverty and violence are multiple and complex. This project explored the gap between causal theories of conflict participation and the growing empirical research on postconflict development, by measuring subjective and objective empowerment and disempowerment in context. It examined how discrepancies between individuals' wartime and peacetime opportunities and experiences affect their socioeconomic reintegration, incentives to revert to violence, and the pathways out of poverty.
A comparative analysis of the documentation of torture and ill-treatment in low-income countries (Bangladesh, Kenya, Nepal) May 2014 - August 2016 Tobias Kelly UNIVERSITY OF EDINBURGH, UK In many low-income countries, violence is endemic. Among urban populations, the poor are the most vulnerable to torture and illtreatment and the least able to access forms of accountability. The documentation of torture and ill-treatment can play a key role in improving access to justice and human security. This comparative analysis of the challenges faced by those attempting to document violence also included the development of a survey technique and policy recommendations.

\section{A comparative study of effectiveness and cost-effectiveness of alternative poverty eradication interventions in extremely poor areas of northern Ghana \\ (Ghana)}

October 2016 - October 2019

Patrick Nolen

UNIVERSITY OF ESSEX, UK

This research focuses on the factors that shape pathways into and out of poverty and people's experience of these. It explores how policy can create sustained routes out of extreme poverty in ways that can be replicated and scaled up. 
The study will also assess the effectiveness and cost-effectiveness of alternative poverty eradication projects and their scalability and sustainability.

\section{Achieving policy coherence in challenging environments: risk management and aid culture in Sudan and Afghanistan (Afghanistan, Sudan) \\ October 2010 - January 2013 \\ Mark Duffield \\ UNIVERSITY OF BRISTOL, UK}

This two-year research programme explored the implications of risk management for comprehensive programming in fragile states among $U N$ agencies and international NGOs, including the impacts upon the ambitious policy goals of political transformation. It drew on a number of ethnographic methodologies including interviewing, focus group meetings, and multi-stakeholder workshops. The main research sites were urban gated communities and fortified aid compounds that together constitute an archipelago of international aid.

Agency and governance in contexts of civil conflict (Colombia, India, Lebanon, Niger, South Africa) September 2010 - November 2013

Patricia Justino INSTITUTE OF DEVELOPMENT STUDIES (IDS), UK Violent conflict results in enduring constraints to development. However, violence has an instrumental role beyond destruction and can be used strategically by political actors to promote social transformation. The research analysed how the relationship between populations living in areas of conflict, and armed non-state actors controlling or contesting those areas, can result in forms of local governance and order. It explored how these, in turn, affect the access to, and effectiveness of, livelihoods.

In many low-income countries, violence is endemic. Among urban populations, the poor are the most vulnerable to torture and ill-treatment and the least able to access forms of accountability.

\begin{abstract}
Aid salary discrepancies and development workers' performance

(China, India, Malawi, Papua New Guinea,

Solomon Islands, Zambia)

March 2007 - February 2010

Stuart Carr

MASSEY UNIVERSITY, NEW ZEALAND

This research focused on documenting the extent of salary discrepancies, exploring their consequences for work performance, and determining the potential for salary alignment. It also examined harmonisation to boost cooperative work performance, build capacity and more effectively address poverty reduction challenges. The study contributed to an understanding of the salary gap that often exists between aid workers, whether national or expatriate, volunteer or expert, or among local personnel working for different aid agencies.
\end{abstract}

\section{Alcohol control, poverty, and development in South Africa}

(South Africa)

November 2010 - December 2013

Clare Herrick

KING'S COLLEGE LONDON, UK

This research explored how the lived relationships between alcohol control (as a debate, field of study, policies and practices), poverty, and development in South Africa are manifested among Cape Town's poorest residents. It focused on the practices and consequences of drinking as a platform from which to develop a renewed approach to the contemporary politics of a developing city.

\section{An experimental analysis of network and} group formation for collective action (Zimbabwe)

February 2008 - January 2010

Marcel Fafchamps

UNIVERSITY OF OXFORD, UK

This study used data from a field experiment and a quasi-experiment to investigate group formation for collective action in 19 African villages. The field experiment involved a game that mimicked situations in which development agencies, non-governmental organisations, or 
government bodies invite villagers to form groups rapidly in order to address a shared problem.

\section{Armed group governance and the sustainability of environmental resources: the case of the Philippines (Philippines)}

October 2017 - March 2019

Ana Maria Ibáñez

UNIVERSITY OF THE ANDES, COLOMBIA

This research focuses on understanding the relationship between armed factions and fishing communities in the Philippines. The region's armed conflict has induced a deep militarisation of local economics, politics and societies but there is limited knowledge of how this has affected the fishing sector, the conservation of maritime resources, and how local fishing societies manage common fisheries, access sustainable livelihoods, and build resilience to poverty.

\section{Assessing the impact of the food system on} poverty, nutrition and health, and environmental sustainability in urban Ethiopia

\section{(Ethiopia)}

September 2017 - February 2019

Wafaie Fawzi

HARVARD UNIVERSITY, USA

A greater understanding of the effects of food systems on nutrition, health, poverty, and the environment is necessary to inform the development of optimal food systems. Using mixed methods (including a quantitative household survey and qualitative value chain analysis) to assess the food system for protein source foods among an urban population, the research will examine a developing country food system and its effects on nutrition, health, and the environment.

\section{At the end of the feeder road: assessing the impact of track construction for motorbike taxis on agrarian development in Liberia (Liberia, Sierra Leone) \\ June 2015 - May 2018 \\ Krijn Peters \\ SWANSEA UNIVERSITY, UK}

Transporting harvest from farmstead to village, or road, or market is a cumbersome task that often falls to women and children. A low-cost alternative, such as transport by motorbike, could relieve both women and children of this task. This research explored whether it is possible to foster market-led agricultural growth and poverty alleviation in relation to a locally driven rural transport revolution based on the motorbike taxi.

\section{Averting 'New Variant Famine' in Southern Africa: building food-secure livelihoods with AIDS-affected young people \\ (Lesotho, Malawi) \\ May 2007 - April 2009 \\ Nicola Ansell \\ BRUNEL UNIVERSITY, UK}

This research examined the impacts of the AIDS pandemic on the livelihoods of young people in rural Malawi and Lesotho. Reports suggested a link between the impacts of AIDS on children and their prospects of food security in adult life. Children whose parents die of AIDS may fail to inherit land or other productive assets, and transmission of knowledge and skills between the generations may be disrupted, leaving young people ill-prepared to build food-secure livelihoods for themselves.

\section{Avon in Africa: reducing poverty through global exchange}

(South Africa)

April 2008 - June 2010

Linda Scott

UNIVERSITY OF OXFORD, UK

This study assessed the size and sustainability of the income Avon representatives earn, as well as the financial and social risks they must take to be in this system. It explored the way this selling system affects the communities into which it is introduced to determine whether the Avon scheme generates new wealth for impoverished communities or whether it simply redistributes scarce resources among the poor.

\section{Basic entrepreneurship: a means for transforming the economic lives of the poor?} (Bangladesh, Pakistan, Uganda) January 2014 - December 2017 Robin Stuart Burgess 


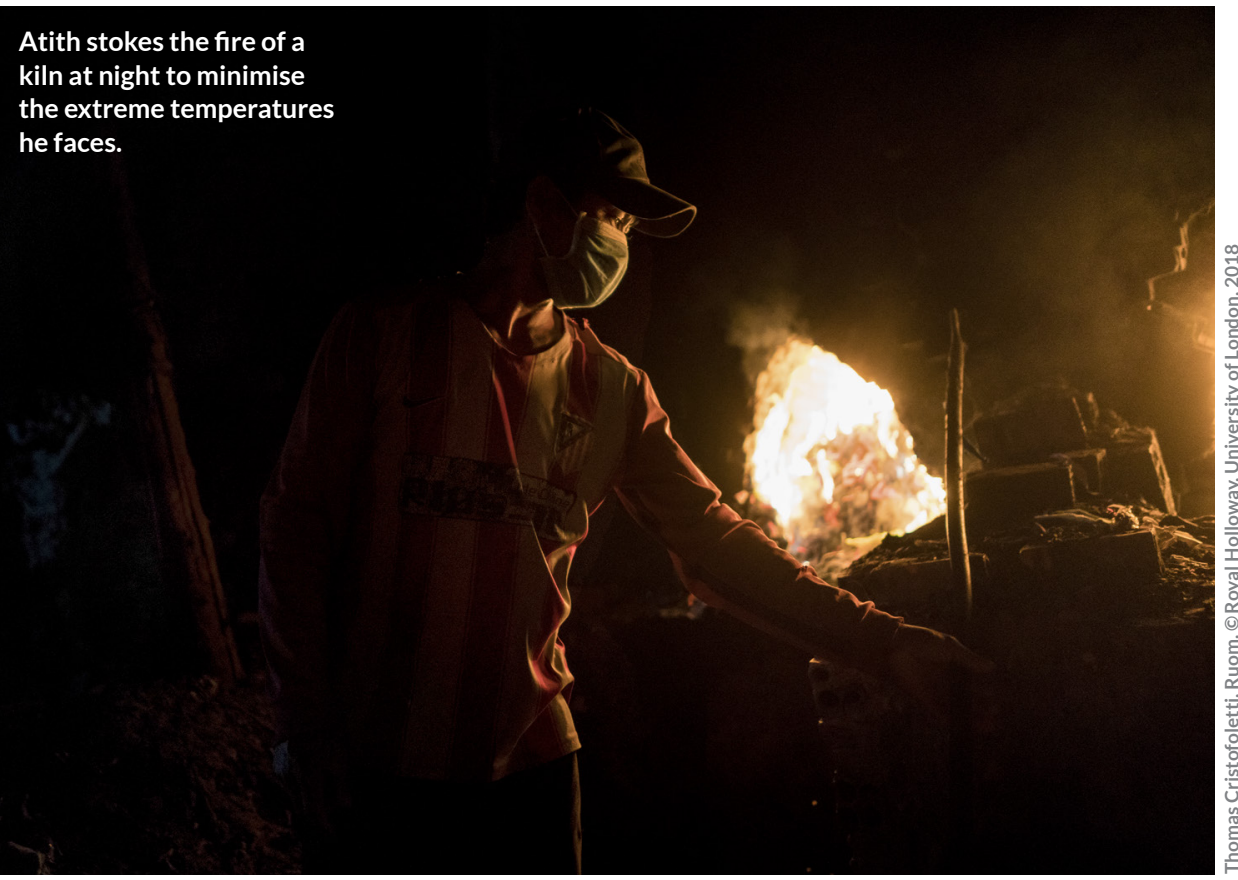

LONDON SCHOOL OF ECONOMICS AND POLITICAL SCIENCE (LSE), UK

This project examined randomised evaluations of an innovative anti-poverty programme which tackles capital and skills constraints at the same time, in an effort to encourage occupational change among the world's poorest women. It aimed to determine if, after acquiring skills and capital to encourage entrepreneurship, poor women alter their occupational choices and could permanently exit poverty.

\section{Biomedical and health experimentation in} South Asia: critical perspectives on collaboration,

\section{governance and competition}

(India, Nepal, Sri Lanka)

September 2010 - February 2013

Roger Jeffery

UNIVERSITY OF EDINBURGH, UK

Experimental scientific enquiry, clinical trials and innovative public health programmes are being carried out on an increasing scale in the global South with considerable potential for development efforts. This comparative study of three South Asian countries focused on creating new social forms such as: contract research organisations, training courses, consultancies, dedicated units in hospitals and universities and site management organisations.

\section{Blood bricks: examining the climate change- modern slavery nexus in the Cambodian}

\section{construction industry}

(Cambodia)

September 2017 - February 2019

Katherine Brickell

ROYAL HOLLOWAY, UNIVERSITY OF LONDON, UK

This research examines the interlinkages

between climate change, different axes of

structural inequality (such as gender and age),

and vulnerability to trafficking into modern

slavery. The project asks who is most at the 'receiving end' of climate change, who is most likely to enter into modern slavery, and who has fewer capabilities and resources than others to adapt to climate change in alternative ways? 
Bridging the gap: examining disability and development in four African countries (Kenya, Sierra Leone, Uganda, Zambia)

April 2015 - June 2018

Nora Groce

LEONARD CHESHIRE DISABILITY, UK

There is growing evidence that as countries make progress towards development, disabled people fall behind. This research contributed to understanding how this occurs and what can be done to bridge the gap. It explored the correlation between common systemic barriers experienced by disabled people when accessing services and multidimensional poverty.

\section{Broadcast media, ICT-generated public} opinion and political accountability in Africa (Kenya, Zambia)

October 2012 - October 2014

Sharath Srinivasan

UNIVERSITY OF CAMBRIDGE, UK

This research examined how the poorest and least politically enfranchised use new communication technologies to voice opinion and engage in a public debate, and the effects on modes of political accountability. Through detailed qualitative case studies, the project explored the potential for digital communications and liberalised media sectors to promote more responsive and inclusive democratic governance. This project is also known as: Politics and Interactive Media in Africa (PIMA).

\section{Building a brighter future: a randomized evaluation of slum-housing upgrading (El Salvador, Peru)}

January 2008 - December 2010

Paul Gertler

UNIVERSITY OF CALIFORNIA, BERKELEY, USA

A controlled randomised trial estimated the causal effects of a low-cost housing intervention on multiple dimensions of welfare in EI Salvador and Peru. In both countries urban slums have grown rapidly as a consequence of extreme rural poverty and civil conflict.

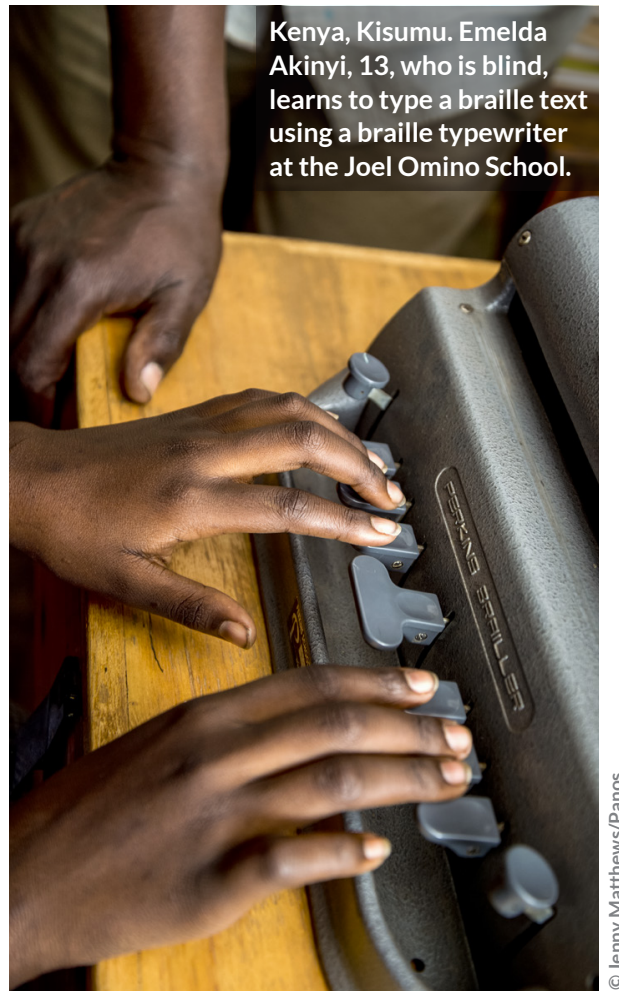

Can financial products reduce poverty and vulnerability? Experimental evidence from Benin on the impact of access to saving accounts and microcredit (Benin)

August 2016 - July 2019

Philippe LeMay-Boucher

HERIOT-WATT UNIVERSITY, UK

Microcredit can be a key tool in addressing poverty; however, if poor people prefer to put their savings in a secure account, this could be better served with access to affordable formal saving accounts. This project analyses the financial needs of poor people by comparing formal (microcredit and microsavings) and informal financial services. A randomised controlled trial in Benin will test which tools are more effective in helping individuals to reduce poverty and vulnerability. 
Challenging the development paradigm: assessing accountability and equity of global institutions in climate-change governance

\section{responses to the poor}

\section{(Ghana)}

July 2010 - November 2013

Susannah Mayhew

LONDON SCHOOLOF HYGIENEAND TROPICALMEDICINE, UK Without equitable, accountable structures and processes of policy and decision making, it will not be possible to achieve a global response to climate change, or ensure the sustainability of economic development. This project examined how global and national organisations tasked with responding to climate change-induced threats to poverty alleviation and public health are preparing themselves institutionally to meet these challenges.

Challenging the investment climate paradigm: governance, investment and poverty reduction

\section{in Vietnam}

(Vietnam)

October 2010 - February 2013

Hubert Schmitz

INSTITUTE OF DEVELOPMENT STUDIES (IDS), UK

Enormous energies and resources are devoted to institutional reform in order to improve the investment climate and promote economic growth. The assumption is that institutional reform comes first and investment follows. This project examined this key assumption and investigated whether the widely assumed sequence applies in the real world or whether, in fact, investment and growth provide the impetus for institutional reform.

\section{Microcredit can be a key tool in} addressing poverty; however, if poor people prefer to put their savings in a secure account, this could be better served with access to affordable formal saving accounts.
Charity, philanthropy and development in

\section{Colombo, Sri Lanka}

(Sri Lanka)

December 2011 - June 2014

Roderick Lennox Stirrat

UNIVERSITY OF SUSSEX, UK

This study investigated charity and charitable organisations in Colombo, Sri Lanka, where long-standing ideologies of giving intermingle, interact, and coexist with global ideas about the nature of charity and the relationship between charity and development.

Children, transport and mobility in subSaharan Africa: developing a child-centred evidence base to improve policy and change thinking across Africa

(Ghana, Malawi, South Africa)

May 2006 - April 2010

Gina Porter

DURHAM UNIVERSITY, UK

The research focused on the mobility constraints faced by children in accessing health, educational and other facilities in subSaharan Africa, and sought to address the lack of direct information on how these constraints impact on children's current and future livelihood opportunities, and a lack of guidelines on how to tackle these problems.

Choice, constraint and the gender dynamics of labour markets in West Bengal

(India)

August 2016 - July 2019

Naila Kabeer

LONDON SCHOOL OF ECONOMICS AND POLITICAL SCIENCE (LSE), UK

This study explores the factors which shape pathways into and out of poverty, how people experience these factors, and the role of policy in creating sustained routes out of poverty. It seeks a better understanding of the barriers to women's labour force participation in the Indian context through a detailed case study of the gender dynamics of labour markets in the state of West Bengal. 


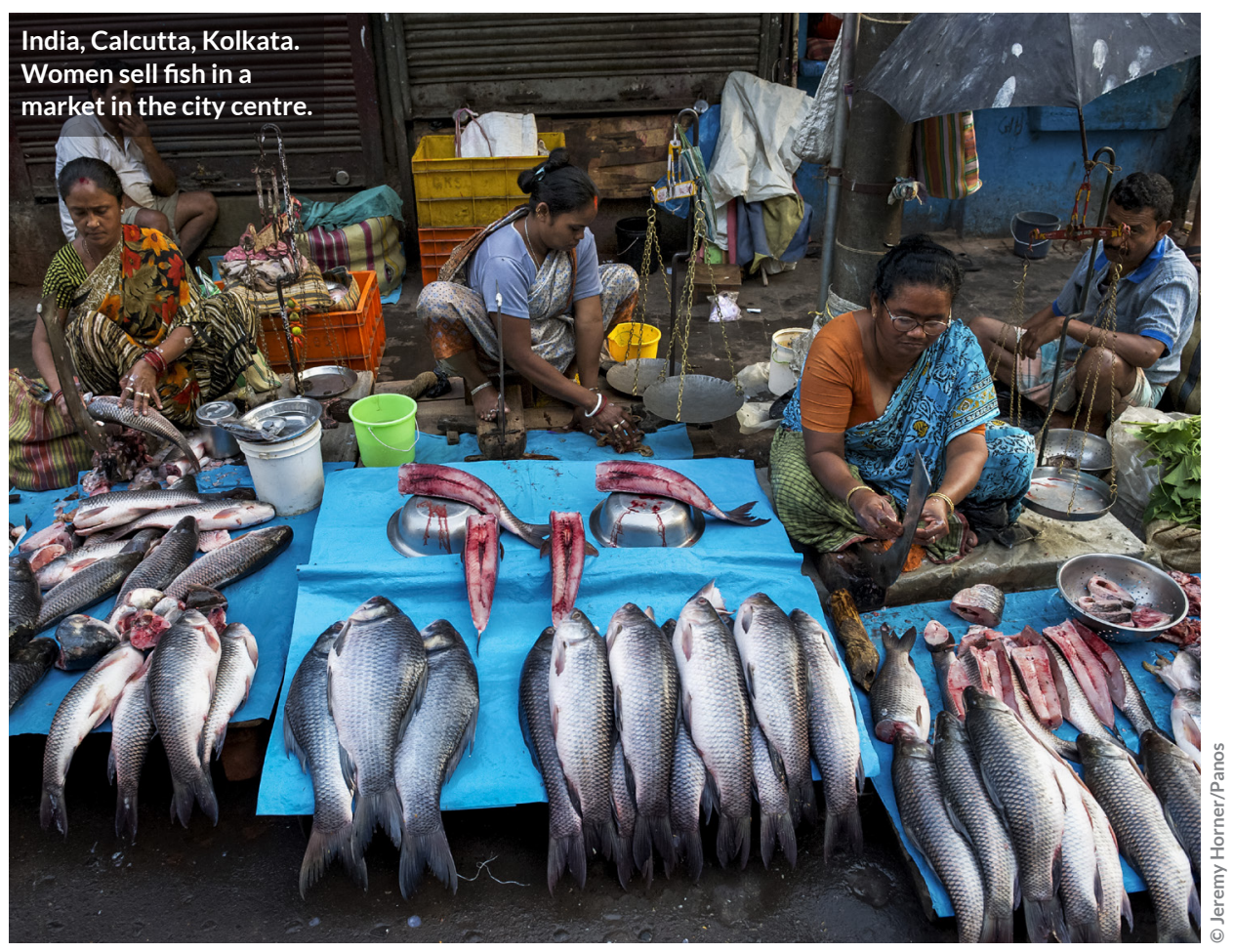

Choice, constraints and the gender dynamics of labour markets in Bangladesh

(Bangladesh)

April 2014 - March 2017

Naila Kabeer

LONDON SCHOOL OF ECONOMICS AND POLITICAL SCIENCE (LSE), UK

Labour markets are recognised as key institutional routes through which the benefits of growth are distributed across populations and are significant from a gender perspective. Yet, despite high rates of growth in recent decades, marked gender disparities in labour market outcomes persist across much of South Asia. This project sought to understand the gender dynamics of the labour market in the context of Bangladesh.

\section{Chronic poverty and aspirations failures}

(Argentina, India)

May 2008 - December 2009
Sayantan Ghosal

UNIVERSITY OF WARWICK, UK

Chronic poverty is a condition that requires an understanding of the processes that make, and keep, people poor. The economic analysis of chronic poverty must take into account the interaction between external circumstances (initial wealth social status, health) and intrinsic psychological factors (aspirations, self-confidence, beliefs). This project sought to formulate and analyse a formal model of social interaction where the psychological factors are linked to their extrinsic circumstances across individuals.

Citizens and the state in urban India: an in-depth investigation on emergent citizenship and public goods provision

(India)

August 2010 - September 2012

Michael Walton

CENTRE FOR POLICY RESEARCH, INDIA 
In Indian cities many people live in marginal areas with insecure housing and inadequate provision of public services, such as water and sanitation, electricity, garbage collection, and policing. The research explored how 'failures' in service delivery relate to interactions between individuals, their networks, and state actors. It analysed the nature and formation of citizenship in marginal areas in order to develop practical policy proposals for state actors and civil society activists.

\section{Community and institutional responses to the challenges facing poor urban people in an era of global warming in Bangladesh \\ (Bangladesh)}

October 2010 - March 2014

David Hulme

UNIVERSITY OF MANCHESTER, UK

Climate change and climate variability is impacting on the living conditions and livelihoods of poor people. Yet most governments in developing countries see climate change purely as a rural problem which impacts on agriculture and food security. This research aimed to fill an important knowledge gap by exploring how to effectively address the problems of poor urban people in a context of rapid climate change.

\section{Contested development? Intimate partner violence and women's employment in urban and rural Tanzania}

(Tanzania)

April 2008 - March 2010

Charlotte Watts

LONDON SCHOOL OF HYGIENEAND TROPICAL MEDICINE, UK

This 18-month study involved the analysis of high-quality data collected from Dar es Salaam and a contrasting rural site, Mbeya. The survey asked women about their experience of physical and sexual partner violence. The study sought to improve an understanding of the relationship between women's employment and the risk of intimate partner violence in urban and rural Tanzania, and to explore the policy and conceptual implications.
Climate change and climate variability is impacting on the living conditions and livelihoods of poor people. Yet most governments in developing countries see climate change purely as a rural problem with impacts on agriculture and food security.

\section{Demographic and poverty dynamics in an African population with high AIDS mortality and implications for social policy}

(South Africa)

October 2006 - March 2010

Ian Manfred Timaeus

LONDON SCHOOL OF HYGIENE AND TROPICAL MEDICINE, UK

This research contributed to an improved understanding of the impact of deaths of working-age adults on household welfare, households' responses, and the determinants of differential vulnerability and resilience. It examined the effects of demographic change, including the AIDS epidemic, on poverty dynamics across the life course in South Africa and assessed the social policy interventions designed to mitigate the impact of the epidemic and their distributional implications.

\section{Determinants of health-care decisions: children's health in Mali \\ (Mali)}

October 2013 - March 2015

Mark Robert Dean

INNOVATIONS FOR POVERTY ACTION, USA

A randomised controlled trial of two health-care policies which examined the provision of free primary care, and regular visits from health workers to promote good practices with mothers. It explored the effects policies have on the use of health-care resources by mothers of young children - in particular when they seek medical care, who they seek care from, and use of preventive measures such as mosquito nets and water purification. 
Development discourses: higher education and poverty reduction in South Africa

(South Africa)

July 2008 - December 2009

Melanie Jane Walker

UNIVERSITY OF NOTTINGHAM, UK

This project investigated the equity trajectory of higher education institutes and their role as 'engines of reform', and developed a conceptual and practical application of human development and wellbeing through professional education and graduate professionals.

\section{Development frontiers in crime, livelihoods} and urban poverty in Nigeria (FCLP)

(Nigeria)

January 2018 - January 2019

James Cheshire

UNIVERSITY COLLEGE LONDON, UK

This mixed methods research aims to bring together key development concerns related to

sustainable livelihoods, social vulnerability, and poverty. It seeks to build an alternative account of 'insecurity and crime' in African cities where the lines between legality and illegality, formality and informality, licit and illicit work, are often blurred in practice.

\section{Development frontiers in low-income} countries: the role of youth, sport and cultural interventions

\section{(Cape Verde, Nepal, Timor-Leste)}

October 2017 - April 2019

Richard Giulianotti

LOUGHBOROUGH UNIVERSITY, UK

This project investigates the role of sport, cultural and educational programmes in promoting sustainable development among young people in low-income countries (LICS), specifically to tackle poverty, conflict in fragile states, environmental sustainability, and gender inequality. It seeks to fill knowledge gaps to enhance knowledge of these programmes with young people in LICs, improve programme efficacy in policy and practice, and work with key stakeholders to secure social change.
Development in the 'raw': what livelihood trajectories and poverty outcomes tell us about welfare regimes and resilience in Afghanistan

(Afghanistan)

May 2008 - December 2010

Paula Kantor

UNIVERSITY OF EAST ANGLIA, UK

This study examined livelihood trajectories and poverty outcomes among rural Afghan households, examining change from a 2002-03 panel set of household data. It explored how households have formed their livelihoods and what evidence there is of resilience and agency and also of constraints imposed by the institutional contexts in which the households function.

Does 'shame-proofing' anti-poverty programmes improve their effectiveness? Theory of change and impact policy evaluation in cross-national settings

(Global)

July 2015 - April 2018

Robert LLoyd Walker

UNIVERSITY OF OXFORD, UK

Shame may serve to perpetuate poverty through eroding individual agency, while policies that stigmatise could be counterproductive in adding to the debilitating effects of shame. This study investigated the effectiveness of social protection policies that have been 'shameproofed' against those which have not.

Economic recovery in post-conflict cities: the role of the urban informal economy

(Egypt, Liberia, Nepal, Pakistan)

January 2016 - January 2019

Alison Brown

CARDIFF UNIVERSITY, UK

Political upheaval or violent conflict is often characterised by a fundamental failure of governance and economic collapse. With a focus on urban areas in post-civil war settings, and on cities affected by protest or ongoing turf wars, this research explores the complex drivers of conflict and links to the informal economy, 
the factors that support or inhibit its growth, and the role of local government in post-conflict economic recovery.

\section{Embedding poor people's voices in local}

governance: participation and political

\section{empowerment in India}

(India)

January 2008 - November 2010

Glyn Williams

UNIVERSITY OF SHEFFIELD, UK

Poor people's lack of voice and influence are globally recurring themes in their own accounts of their poverty, and are indicative of their wider political disempowerment. This project evaluated attempts to tackle this core element of poverty through local governance reform. It explored the extent to which participatory initiatives within local governance help to enhance poor people's opportunities for political empowerment.

\section{Energy gardens for small-scale farmers in} Nepal: institutions, species and technology (India, Nepal)

October 2013 - March 2015

Jonathan Lovett

UNIVERSITY OF LEEDS, UK

This project sought to forge new links across disciplines by integrating research on the institutional economics of energy and technology transfer with the knowledge of botanists and engineers. It investigated the controversies surrounding use of biomass and biofuels for energy production by utilising indigenous plant species within the context of small-scale poor farmers and communities in Nepal using 'Energy Gardens'.

Poor people's lack of access to information about processes which might assist or injure them is an important facet of their poverty in less-developed countries.
Energy on the move: longitudinal perspectives on energy transitions among marginal populations (a comparative study) (Bangladesh, Nepal, Nigeria, South Sudan) October 2017 - March 2019

Ben Campbell

DURHAM UNIVERSITY, UK

Lack of access to clean energy limits economic development, stifles people's life chances, and traps millions into extreme poverty. This project examines the energy practices of very poor women, men, and young people living in informal settlements in peri-urban situations in Nigeria, South Sudan, Nepal and Bangladesh.

\section{Energy scarcity, food supply chain}

transformation, and poverty reduction in the emerging economies: the case of Brazil,

China, and India

(Brazil, China, India)

October 2012 - December 2015

Kevin Chen

INTERNATIONAL FOOD POLICY RESEARCH INSTITUTE (IFPRI), USA

This research contributed to greater understanding of the links among energy costs and use, the transformation of food supply chains and technologies, and poverty alleviation. It analysed horticulture and dairy supply chains in Brazil, China, and India to assess how energy costs are generated and affect behaviour in various segments of the supply chain. It explored the implications for food costs to consumers and incomes to producers.

Enforcing transparency: enhancing poor people's access to information in India (India)

January 2008 - April 2011

James Manor

UNIVERSITY OF LONDON, UK

Poor people's lack of access to information about processes which might assist or injure them is an important facet of their poverty in less-developed countries. This project assessed India's National Rural Employment Guarantee Act, and related transparency mechanisms, in two mainstream 
Indian states (Rajasthan and Madhya Pradesh). It aimed to ascertain how poor people are provided with information about their rights under this legislation.

\section{Engaging teachers in peace-building in post-conflict contexts: evaluating education interventions in Rwanda and South Africa}

(Rwanda, South Africa)

September 2014 - November 2017

Yusuf Sayed

UNIVERSITY OF SUSSEX, UK

This study contributed to understanding about the conditions under which education interventions focused on teachers can promote peace, and mitigate and reduce violence. It also explored the measures and processes that increase the effectiveness of programmes in conflict-affected situations.

\section{Ethnic minority underdevelopment in Vietnam}

(Vietnam)

December 2006 - February 2008

Robert John Baulch

INSTITUTE OF DEVELOPMENT STUDIES (IDS), UK

This project investigated why ethnic minority peoples have failed to share equally in the benefits of Vietnam's recent rapid economic growth, despite the plethora of government programmes designed to assist them. The project combined rigorous quantitative analysis of three rounds of household survey data from the 1990 s and early 2000 s with a qualitative review of the policy implementation process at different levels of government in three provinces.

\section{Expanding education to reduce poverty: public}

\section{and private provision}

(Ghana)

June 2011 - November 2013

Kim Lehrer, Francis John Teal

UNIVERSITY OF OXFORD, UK

Research conducted in Ghana informed an evaluation of two closely related policy questions. The first focused on how any expansion of education should be effected (the rates at which it should be expanded at various levels). The second examined how this expansion
Can labour-saving genetically modified (GM) technology - such as GM white maize - support agricultural growth in Africa or would this result in underemployment in rural areas?

should be funded, and whether policies should seek to influence the divide between the public and private sector.

\section{Factor endowments, biased technological change, wages and poverty reduction: can genetically modified crops bring a green revolution to Africa?}

(Malawi, South Africa)

November 2006 - October 2008

Colin Graham Thirtle

IMPERIAL COLLEGE LONDON, UK

Can labour-saving genetically modified (GM) technology - such as GM white maize - support agricultural growth in Africa or would this result in underemployment in rural areas? To respond to this question, researchers combined a study of the past impacts of biased technical change and factor endowments with surveys of the impacts of GM maize on employment and the incomes of small farmers in Africa.

\section{Farm scale and viability: an assessment of} black economic empowerment in sugar production in Mpumalanga province, South Africa (South Africa)

August 2011 - January 2015

Philip Woodhouse

UNIVERSITY OF MANCHESTER, UK

This project undertook a study of sugar farms in Mpumalanga province, South Africa, where, following land reform, black-owned agriculture operates on both small- and large-scale production units. The research collected and analysed new data using farm surveys and interviews with farm owners and employees, as well as analysing existing data. 


\section{Female labour supply and the escape from poverty: new evidence from household data (Bangladesh, Ethiopia, Pakistan, Rwanda) \\ September 2015 - December 2018 \\ Andy Mckay \\ UNIVERSITY OF SUSSEX, UK}

This study utilises household survey data from four African and Asian countries (Bangladesh, Ethiopia, Pakistan, and Rwanda) to examine in depth, and on a comparable basis, the evolving nature of female labour supply in low-income countries over the past two to three decades, and to analyse how this has been associated with poverty reduction.

\section{Field experiment on the behavioural} foundations of inter-group discrimination and its effects on public good provision in India (India)

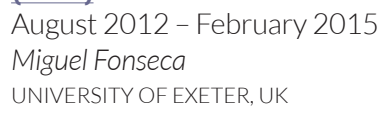
economic performance in rural West Bengal, India. It built on existing household survey work on religious- and caste-based social exclusion in villages through field experiments to understand the decisions of agents affected by poverty and explore the extent to which preferences regarding caste, ethnicity, and religion determine their willingness to socially exclude others, or for themselves to be excluded.

\section{Finance and formalisation as mechanisms for poverty reduction in Africa}

(Ghana, Tanzania)

February 2008 - October 2009

Francis Teal

UNIVERSITY OF OXFORD, UK

This research explored how access to microfinance and processes of formalisation can impact on poverty by investigating two policies in Ghana and Tanzania: (1) the expansion of microcredit services into randomly selected communities by several partner NGOs; and (2) the implications of a process of formalising business structures underway in Tanzania.
Food riots and food rights: the moral and political economy of accountability for hunger (Bangladesh, India, Kenya, Mozambique) October 2012 - October 2014 Naomi Therese Hossain INSTITUTE OF DEVELOPMENT STUDIES (IDS), UK Focusing on the 'food crisis' since 2007, this research examined right-to-food movements and riots over food prices in Bangladesh, India, Kenya and Mozambique. The project aimed to improve understanding of how to hold governments to account over hunger, enable policymakers to better anticipate and monitor the effects of food price volatility, and create opportunities for activists to engage with policymakers and government officials.

\section{Gender equity in contract farming in Eastern} Africa

(Malawi, Tanzania)

October 2013 - June 2015

Martin Prowse

UNIVERSITY OF COPENHAGEN, DENMARK

Contract farming is a form of vertical integration within agricultural commodity chains so firms have greater control over the production process and final product. This project evaluated the gender-specific elements within existing contract farming operations and whether gender-specific clauses increase the benefits smallholders and firms accrue from the relationship.

\section{Gender norms, labour supply and poverty reduction in comparative context: evidence} from rural India and Bangladesh (Bangladesh, India) January 2014 - November 2017 Wendy Olsen

UNIVERSITY OF MANCHESTER, UK

The project measured the gender impact of poverty alleviation interventions in rural India and Bangladesh and how this impact has been mediated through social norms. It examined the differing attitudes about women's work (influenced by social, cultural, economic and political factors), how these attitudes affect women's work, as well as how people's attitudes are influenced by anti-poverty interventions. 


\section{Gender, education and global poverty reduction initiatives \\ (Kenya, South Africa)}

October 2007 - March 2011

Elaine Sara Unterhalter

INSTITUTE OF EDUCATION, UK

This research looked at how gender equality in, and through, schooling in contexts of poverty is understood. It explored who participates in implementation and how gender, schooling, and global relations are negotiated. In addition, the research examined the constraints experienced, how these were overcome, and any concerns about global obligations that emerged.

\section{Governance implications of private standards initiatives in agri-food chains \\ (Kenya)}

May 2007 - August 2007

Anne Marie Tallontire

UNIVERSITY OF GREENWICH, UK

Suppliers in agri-food chains are required to comply with a growing set of standards to secure market access. Many standards are 'voluntary' and have been developed and overseen by

organisations from the private sector, sometimes working with NGOs, to promote food safety and quality, good agricultural practice and labour standards. Studying agri-food chains originating in Kenya, this project focused on an analysis of private standards initiatives.

\section{Governing food systems to alleviate poverty in secondary cities in Africa}

(Kenya, Zambia, Zimbabwe)

November 2014 - December 2018

Vanessa Watson

UNIVERSITY OF CAPE TOWN, SOUTH AFRICA

While there has been considerable attention paid to the challenges of African mega-cities, the experiences of smaller urban areas have been relatively neglected. Secondary cities, with populations of less than half a million, are absorbing two-thirds of all urban population growth in Africa. This project focuses on three secondary cities to build a clearer picture of the dynamics of poverty in urban spaces and provide insights for addressing poverty reduction.

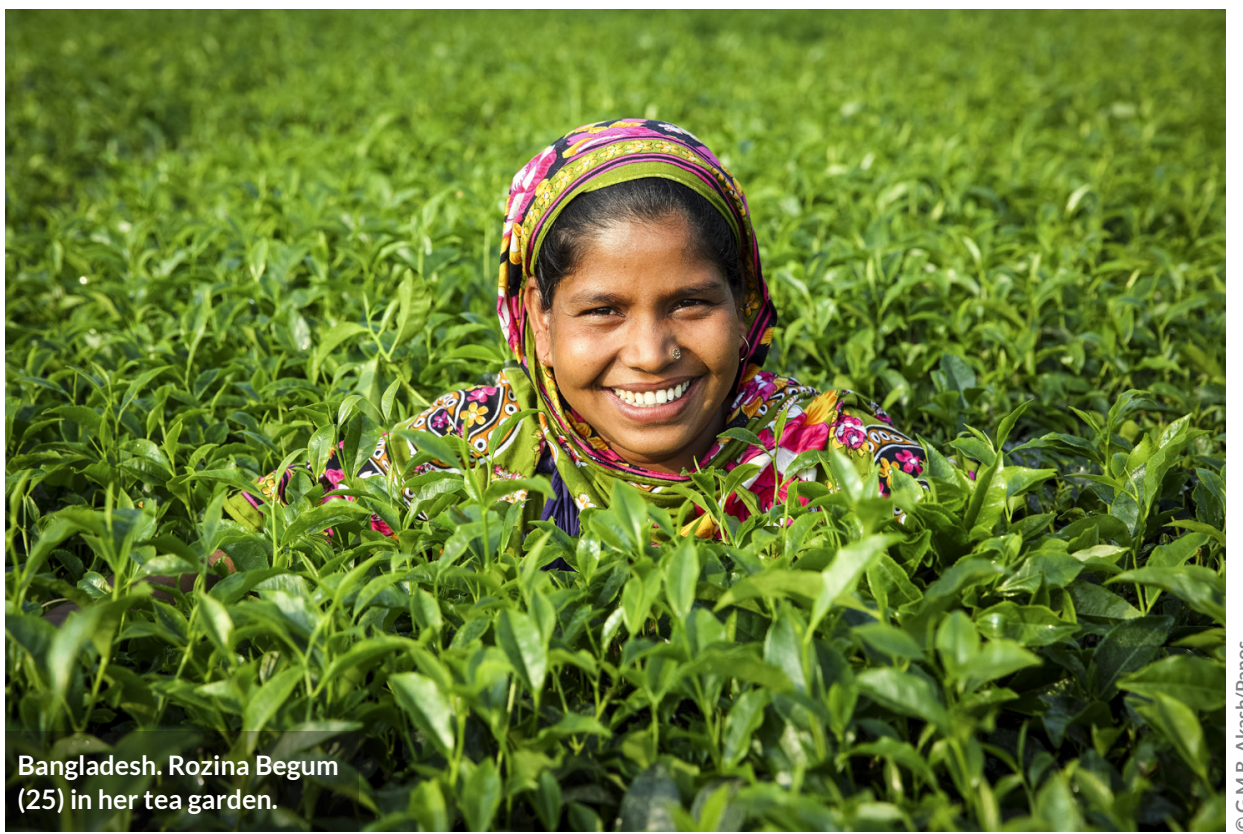




\section{Graduation as resilience \\ (Bangladesh) \\ October 2013 - June 2015 \\ Mushtaque Chowdhury, WMH Jaim \\ BRAC CENTRE, BANGLADESH \\ How important is psychological support \\ such as life planning, confidence building and \\ strengthening social awareness in helping \\ poor women to graduate from poverty in a \\ resilient way? The project explored this question \\ through a model of psychological wellbeing \\ which was tested with poor women involved in \\ Bangladesh's first graduation programme run \\ by BRAC.}

\section{Graduation as resilience stage two}

(Bangladesh)

November 2015 - January 2018

Mushtaque Chowdhury

BRAC CENTRE, BANGLADESH

In stage one, researchers adopted a model of psychological wellbeing and tested it on a sample of women involved in BRAC's graduation programme. Stage two sought to validate the findings and conduct further statistical tests to establish whether (or not) the provision of psychological inputs leads to better programme performance.

Healthy urbanisation: tackling child malnutrition through intervening to change the social determinants of health in informal settlements and slums

(Chile, Kenya)

October 2010 - March 2014

Pat Judith Pridmore

INSTITUTE OF EDUCATION, UK

This project focused on reducing malnutrition in young children through intervening to change the social determinants of health in informal, urban settlements and slums. The central research explored how child malnutrition amongst families living in poverty in informal settlements and slums could be reduced through broadening both community and stakeholder participation and strengthening local political accountability for nutrition.
How important is psychological support such as life planning, confidence building and strengthening social awareness in helping poor women to graduate from poverty in a resilient way?

Holding local leaders and local service provision to account: the politics of implementing a local governance performance index

(Tanzania)

April 2014 - October 2017

Andrew Mushi

MZUMBE UNIVERSITY, TANZANIA

This project adopted participatory processes in three local government areas in Tanzania to create a locally meaningful governance index. It sought to pilot and test the index as a tool for citizen engagement and improvement in local service delivery and governance performance.

How can schools help African children cope with the impacts of disease and poverty? An investigation of 'AIDS competent' schools in rural Zimbabwe

(Zimbabwe)

March 2012 - October 2014

Catherine Magda Campbell

LONDON SCHOOL OF ECONOMICS AND POLITICAL SCIENCE (LSE), UK

The study explored how schools in Africa can help HIV-affected children cope with disease and poverty. It sought to develop a model of the 'HIV competent school' which optimises children's inclusion, support and health.

\section{How can technology improve learning? IT, education and welfare in Niger (Niger)}

February 2014 - January 2017

Jenny Carson Aker

TUFTS UNIVERSITY, USA

Using qualitative and quantitative techniques, including a randomised control trial, the research 
addressed a number of research areas including: the role of mobile phone technology to provide educational content in distance learning, and assessing the impact of the programme on children's educational attainment.

\section{How the urban poor define and measure food} insecurity and nutrition

(Cambodia, Nepal)

September 2017 - February 2019

Cecilia Tacoli

INTERNATIONAL INSTITUTE FOR ENVIRONMENT AND DEVELOPMENT (IIED), UK

Working with poor community organisations led by women in cities in Cambodia and Nepal, this project asks poor people to define and measure food security and nutrition using methods and tools that include the use of innovative, affordable technology. The collection of data and analysis will provide the groundwork for a dialogue that brings together grass-roots organisations of the urban poor, local governments, and other stakeholders.

22 Human development and poverty reduction in developing countries

(Colombia, India, Mexico, Nepal)

June 2006 - May 2009

Orazio Attanasio

INSTITUTE FOR FISCAL STUDIES, UK

The development process is complex, dynamic and incremental, with a variety of factors ranging from nutrition and health care, psycho-social stimuli, to education and the availability of infrastructure playing a central role. Yet their relative importance and the interactions between them are only partially understood. This project sought to gain a thorough understanding of the mechanisms underlying human development by studying human development in its many dimensions.

\section{ICTs and the changing health knowledge economy:} how people find health information in Bangladesh (Bangladesh)

October 2012 - March 2016

Gerald Bloom

INSTITUTE OF DEVELOPMENT STUDIES (IDS), UK

This project examined how the spread of the mass media, increased access to the internet, and high levels of mobile phone use are changing the ways poor people seek health-related information and advice. It explored health information-seeking behaviour in Bangladesh to identify new patterns of behaviour with the potential to spread rapidly.

Identifying barriers to tuberculosis (TB) diagnosis and treatment under a new rapid diagnostic scheme (Ethiopia, Nepal, Yemen)

May 2008 - October 2012

Luis Eduardo Cuevas

LIVERPOOL SCHOOL OF TROPICAL MEDICINE, UK

This study assessed whether improving the efficiency of the diagnosis process for TB leads to increased access to treatment. It identified the barriers preventing adults from completing the diagnostic process in Ethiopia, Nepal and Yemen and explored what changes were required to increase treatment uptake.

\section{Impact assessment based on self-reported attribution in complex contexts of rural} livelihood transformations in Africa

(Ethiopia, Malawi)

September 2012 - September 2015

James Copestake

UNIVERSITY OF BATH, UK

How can the impact of development activities intended to benefit poor men, women and children who are caught up in complex processes of rural transformation best be assessed? This research set out to develop and evaluate a protocol for impact assessment based on self-reported attribution without the use of comparison groups as an alternative to experimental, or quasi-experimental designs, based on statistically inferred attribution.

\section{Impact evaluation of performance-based} contracting for general health and HIV/AIDS

\section{services in Rwanda}

(Rwanda)

February 2008 - January 2012

Stefano Michele Bertozzi

NATIONAL INSTITUTE OF PUBLIC HEALTH, CANADA

An impact evaluation of a performance-based financing scheme for health care, including basic 
preventive and curative health-care services and HIV/AIDS treatment, which was implemented in Rwanda from 2006 to 2008.

\section{Impact of social pensions on multiple dimensions of poverty, subjective wellbeing and solidarity across generations \\ (Kenya)}

January 2017 - June 2019

Gloria Langat

UNIVERSITY OF SOUTHAMPTON, UK

This research seeks to generate robust, urgently needed evidence to address the critical knowledge gaps about the nature and drivers of household, individual-level and intergenerational impacts of Kenya's Older Persons Cash Transfer Programme (OPCTP) and the Programme's overall effects on the wellbeing of older beneficiaries and their families in urban and rural contexts, in order to inform policy debates and thinking on the further development of the OPCTP and similar schemes in SSA.

\section{Impact of urban-rural return migration on} rural economic development in China - with

\section{implications for Vietnam}

(China, Vietnam)

April 2014 - September 2017

Wenfei Winnie Wang

UNIVERSITY OF BRISTOL, UK

This research investigated the impact of urban-rural return migration on rural economic development in China and how results are transferable to China's neighbouring country, Vietnam. It explored the ways that returnees contributed to the local rural economy, their decision-making process, and key institutions and

\section{The development process is complex,} dynamic and incremental, with a variety of factors ranging from nutrition and health care, psycho-social stimuli, to education and the availability of infrastructure playing a central role. policies affecting their entrepreneurial activities. It sought to enrich understanding on the conditions and institutional context that stimulate rural development and help the rural poor exit poverty.

\section{Improving educational evaluation and quality} in China

(China)

May 2008 - January 2011

Sally Thomas

UNIVERSITY OF BRISTOL, UK

This research investigated the nature and extent of school effectiveness in China. It sought to provide new insights and extend current theories about: (1) the impact of student characteristics, and classroom, school and contextual factors on students' attainment and progress, (2) the relevance of these factors in the evaluation of school performance, and (3) how Western approaches to evaluating educational quality have been adapted and developed to take account of local contexts and priorities.

Improving research infrastructure on social assistance

(Global)

September 2016 - February 2019

Armando Barrientos

UNIVERSITY OF MANCHESTER, UK

This project focuses on improving research infrastructure on social assistance, in terms of concepts, indicators and data, which is needed to support comparative analysis of emerging social assistance institutions. It identifies indicators to assess social assistance programmes by collecting information on these for all developing countries for 2000 to 2015 . The research will contribute to gaps in knowledge of the effectiveness, reach and sustainability of social assistance programmes, and will encourage further comparative research.

\section{Improving teacher development and} educational quality in China: examining schools as professional learning communities (China) May 2010 - April 2014

Sally Thomas

UNIVERSITY OF BRISTOL, UK 
The study investigated the nature and extent of teachers' professional development in China as well as the significance of professional learning communities, in order to evaluate and enhance teacher quality and school effectiveness in senior secondary schools. It extended previous (single cohort) models of school effectiveness, employing innovative quantitative methodology (multilevel modelling), by examining improvement in school effectiveness over four consecutive student cohorts and by investigating the impact of teacher development factors on student outcomes and progress.

\section{Incentives for accurate diagnosis: improving health-care quality in Mali}

\section{(Mali)}

August 2015 - July 2017

Anja Sautmann

BROWN UNIVERSITY, USA

Finding ways to deliver high-quality health care to low-income populations in a developing country such as Mali is a critical policy challenge. Evidence indicated that some care may be unnecessary or mistargeted - in particular for malaria. This project sought to identify the leading causes behind overprescription and over-treatment, and test whether alternative incentive regimes can improve care outcomes without producing unnecessary costs.

\section{Infrastructure and development: evidence from India and East Africa}

(Botswana, India, Kenya, Malawi, Tanzania, Uganda, Zambia, Zimbabwe)

January 2007 - June 2010

Robin Stuart Burgess

LONDON SCHOOL OF ECONOMICS AND POLITICAL SCIENCE (LSE), UK

This study addressed a gap in knowledge of whether, and how, infrastructure investments affect poverty and development, focusing on India and East Africa. A database of Indian districts was built for 1870-2000 to examine the mechanisms in which railway and bank branch expansion affect poverty and development, and a panel district dataset for 1950-2000 was created for Botswana, Kenya, Malawi, Tanzania, Uganda, Zambia and Zimbabwe to look at the political economy of road placement.
Insecurity and uncertainty: marginalised young people's living rights in fragile and conflict-affected situations in Nepal and Ethiopia

(Ethiopia, Nepal)

July 2016 - June 2019

Vicky Johnson

UNIVERSITY OF BRIGHTON, UK / GOLDSMITHS,

UNIVERSITY OF LONDON, UK

This project investigates how vulnerability, agency, and rights affect young people's daily lives and how their dreams and identities change as they grow up in settings from busy urban centres to remote rural settings in Nepal and Ethiopia. The project will explore why - in times of conflict and in post-conflict and fragile environmental and social settings - youth reject traditional norms, form new social norms and seek support and leadership in alternative groupings and forms of peer support, such as gangs and extremist groups. This project is also known as: YOUR World Research.

\section{Institutional arrangements in land deals in Africa: local impacts of global resource scarcity (Ghana, Kenya, Zambia)}

August 2012 - February 2016

Ruth Hall

UNIVERSITY OF THE WESTERN CAPE, SOUTH AFRICA

This research contributed to ongoing policy debates about the impacts of and responses to the African 'land rush' through investigating three farming models in Ghana, Kenya, and Zambia: corporate plantations/estates; clusters of large commercial farms; and smallholder outgrower schemes. The comparative study explored: (1) how land deals affect people's resource access, and what forms of accumulation are occurring; and (2) the socially differentiated livelihood and food security impacts of different kinds of land transactions.

\section{Insuring against rural water risk in Africa} (Kenya, Mozambique, Senegal, South Africa)

December 2013 - May 2015

Robert Adrian Hope

UNIVERSITY OF OXFORD, UK

This research examined the potential for microinsurance to address rural waterpoint 


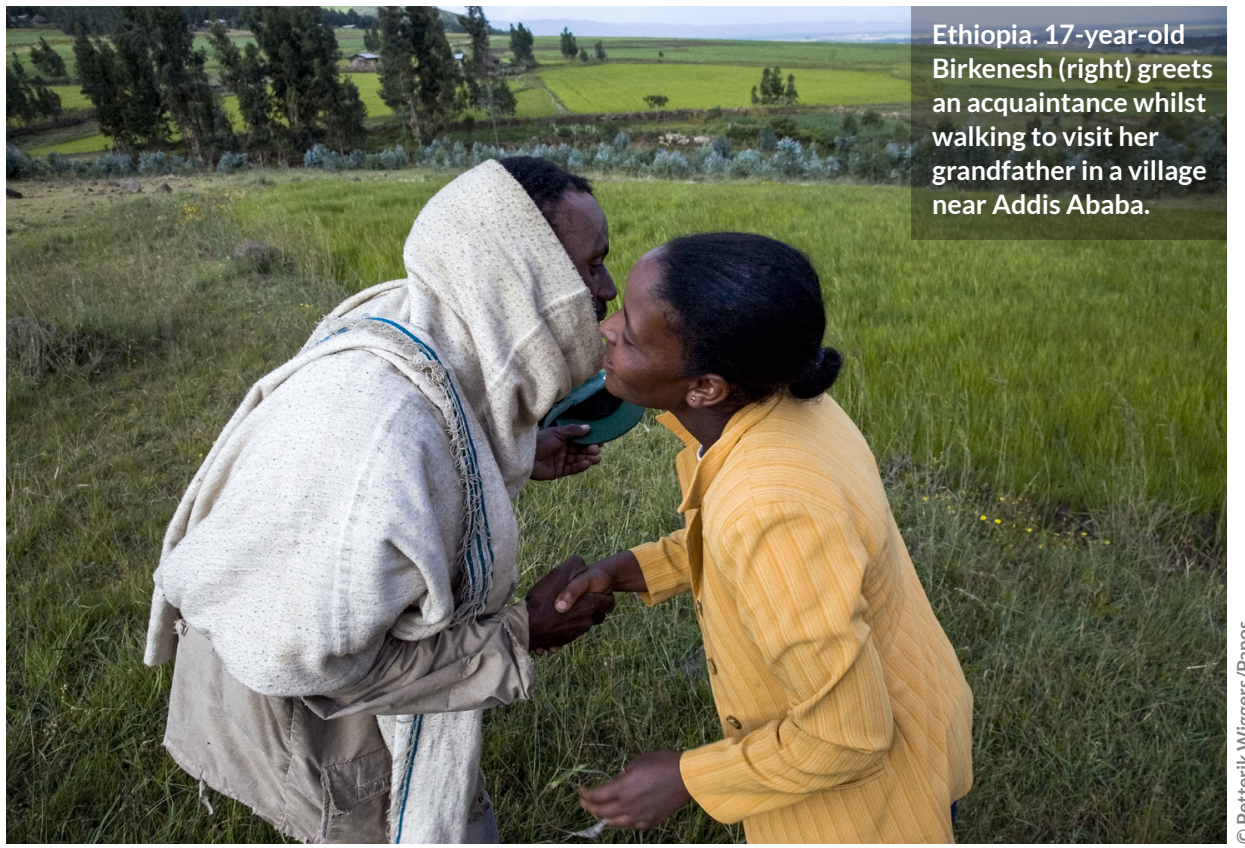

sustainability challenges in Kwale, Kenya.

The findings reveal compelling evidence that under the prevailing community-management approach, financial risk undermines the sustainable operation and maintenance of waterpoints. The results provide instructive guidance for policymakers and practitioners looking to revise and rework approaches for the delivery of sustainable, safe, and reliable rural water services in Kenya and beyond.

\section{Integrated policies to reduce poverty in its} many dimensions

(Nepal, Senegal)

March 2016 - February 2019

Sabina Alkire

UNIVERSITY OF OXFORD, UK

What factors shape pathways into and out of poverty and people's experience of these, and how can policy create sustained routes out of extreme poverty in ways that can be replicated and scaled up? This project uses the AlkireFoster method in new, policy-relevant ways. It will produce new econometric analyses of multidimensional poverty, analyse the determinants of poverty reduction in over 60 countries, and study integrated policy interventions and their effectiveness in reducing poverty.

\section{Inter-agency research on strengthening} community-based child protection for vulnerable children in Sierra Leone (Sierra Leone)

January 2013 - December 2015

Michael Wessells

COLUMBIA UNIVERSITY, USA

Alongside government and the family, the community is a crucial source of potential support for children vulnerable to child protection risks. Community protection policy is often not backed by effective support from aspects of the government system such as social workers and police. This research systematically evaluated the effect of community-led interventions to better link communities with government services and systems to support vulnerable children. 
What are the consequences of new large-scale investments on local institutions, relations, conflict dynamics, and violence? What new hybrid orders emerge, and how successfully do these address local understandings of peace-building and conflict? D

Investigating 'pockets of effectiveness' in developing countries: a new route to building state capacity for development

(Ghana, Rwanda, Uganda, Zambia)

March 2017 - February 2020

Sam Hickey

UNIVERSITY OF MANCHESTER, UK

Study of 'pockets of effectiveness' (PoEs) -

public organisations that deliver development where state capacity is not available. Aims to:

(1) undertake a comparative analysis of the institutional and political conditions through which PoEs emerge and are sustained in different contexts and sectors; (2) identify the role domestic and international actors play in developing and sustaining PoEs; and (3) inform and improve efforts by governments and development agencies to support PoEs in Africa, and developmental governance more broadly.

\section{Is clash of institutions a cause of rural poverty?}

(Guinea, Liberia, Sierra Leone)

January 2013 - December 2016

Erwin Bulte

WAGENINGEN UNIVERSITY, NETHERLANDS

This research investigated whether a 'clash of institutions' is a factor determining poverty in developing countries with a specific focus on land, labour, seeds, and rural credit. It constituted a cooperation between anthropologists and economists to ensure a rounded approach to the full range of institutions at play in determining poverty and poverty alleviation. The research focused on a conflict recovery region - cross-border communities in Guinea, Liberia, and Sierra Leone.

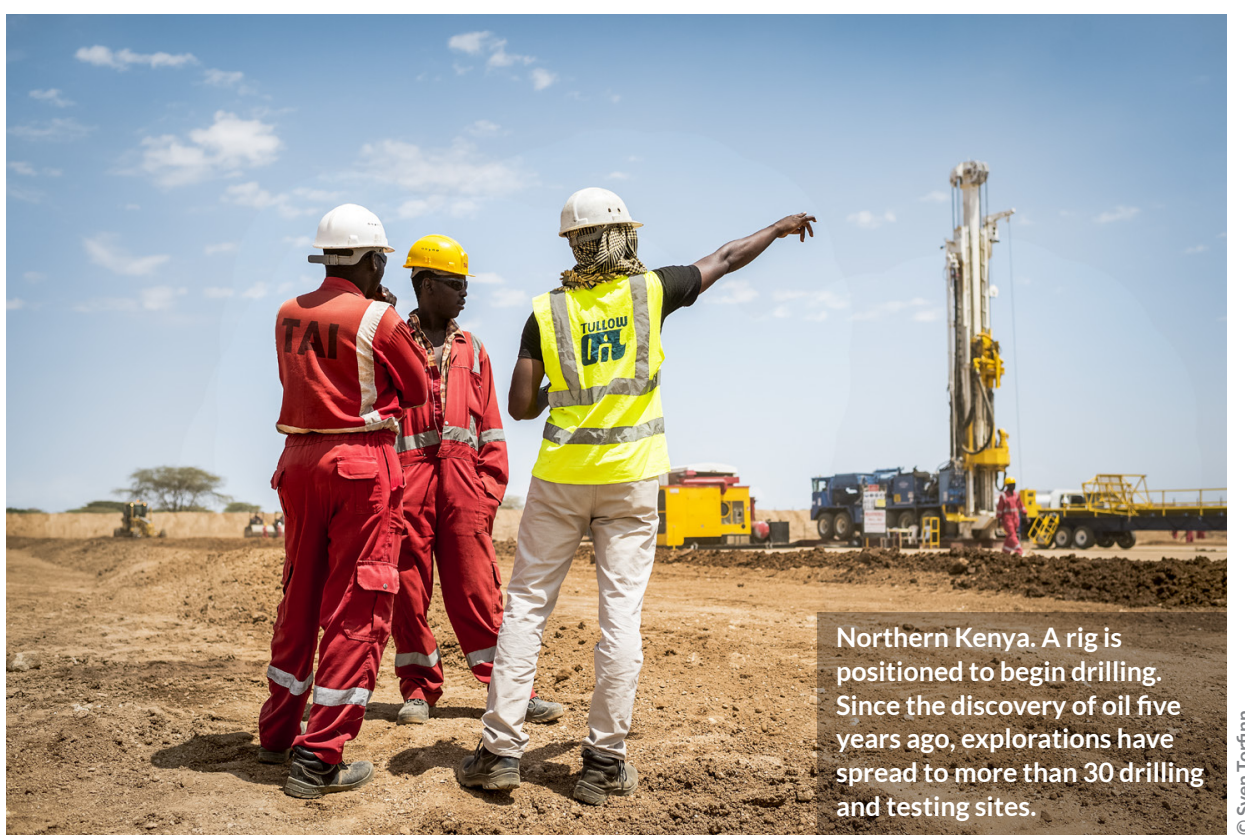




\section{Labour conditions and the working poor in China and India \\ (China, India)}

September 2011 - September 2014

Jens Lerche

SCHOOL OF ORIENTALAND AFRICAN STUDIES (SOAS), UK

The project examined labour conditions at firm level in Shanghai and Delhi; two cities swept up in strong export-led growth. It focused on the garments and construction sectors, the two most important sectors for rural circular migrant labour. It investigated how the working poor in these sectors fared from the global recession, with the objective of examining underlying reasons for labour conditions and labour unrest, including poverty and inequality.

\section{Labour law, development and poverty alleviation in low and middle-income \\ countries \\ (Cambodia, China, India, South Africa)}

March 2013 - March 2016

Simon Deakin

UNIVERSITY OF CAMBRIDGE, UK

This research aimed to understand the role of labour law in alleviating poverty in developing countries, with a focus on the cases of Cambodia, China, India, and South Africa. It addressed issues around the effectiveness of labour law regulation in practice, capacity of regulatory institutions, legitimacy of labour law rules on the ground, and the need for laws to be suited to economic or social conditions.

\section{Large development investment and local} peacebuilding in rural Africa: building and

\section{sustaining peace at the margins}

(Ivory Coast, Kenya)

April 2014 - October 2017

Jeremy Allouche

INSTITUTE OF DEVELOPMENT STUDIES (IDS), UK

Examined how conflict, local governance, and peace-building arrangements in rural Ivory Coast and Kenya are affected by new, largescale investments in resource exploitation to address the following questions: What are the consequences of new large-scale investments on local institutions, relations, conflict dynamics, and violence? What new hybrid orders emerge, and how successfully do these address local understandings of peace-building and conflict? What measures can be taken to promote conflict-sensitive approaches to large investments in marginal rural areas?

\section{Lay and institutional knowledges of domestic violence law: towards active citizenship in rural and urban Cambodia} (Cambodia) January 2012 - October 2015

Katherine Brickell

ROYAL HOLLOWAY, UNIVERSITY OF LONDON, UK

The research concentrated on the Law on the Prevention of Domestic Violence and the Protection of the Victims (2005) in Cambodia. It used a quantitative survey to establish levels of understanding of the 2005 Law and see what associations could be made to different individual, community, and societal factors. The study improved understanding of why investments in law are faltering, and underlined the structural challenges that need to be overcome to enable women's rights claiming.

\section{Left behind in transition? Poverty, social networks and social support amongst older people in Central Asia and the Caucasus (Armenia, Azerbaijan, Georgia, Kyrgyzstan, Moldova, Tajikistan, Uzbekistan)}

August 2007 - December 2009

Jane Falkingham

UNIVERSITY OF SOUTHAMPTON, UK

Examined the living conditions and sources of finance and social support (both state and family) amongst older people living in the seven poorest countries of the former Soviet Union: Armenia, Azerbaijan, Georgia, Kyrgyzstan, Moldova, Tajikistan, and Uzbekistan. The project involved a mixed method design, combining quantitative analysis of the living standards of older people from household survey data with qualitative research providing deep insight into the reality of life for older people. 


\section{Legislating and implementing welfare policy reforms: what works politically in Africa and why? (South Africa) \\ November 2012 - October 2015 \\ Jeremy Seekings \\ UNIVERSITY OF CAPE TOWN, SOUTH AFRICA \\ This project analysed how and why social assistance programmes are adopted in different parts of Africa, drawing comparisons with Brazil and India. The central question was 'What works and what doesn't work politically?' i.e. what makes reforms politically feasible and sustainable? The research covered agenda- setting; elite and public opinion; electoral, inter-and intra-party competition; the roles of civil society, international organisations, and donors; and state institutions, technocrats and bureaucrats.}

\section{Leveraging buying power for development - ethical consumption and public procurement}

\section{in Chile and Brazil}

\section{(Brazil, Chile)}

October 2011 - August 2013

Dorothea Kleine

ROYAL HOLLOWAY, UNIVERSITY OF LONDON, UK

This project explored how the buying choices of the individual and the state can be used as a lever for development, understood as people's freedom to live the life they have reason to value - individually and collectively. The interdisciplinary research team from the UK, Brazil and Chile collaborated with three pioneering NGOs: Ciudadano Responsable, Akatú, and ECRA. The results informed the public debate on this powerful development dynamic.

\section{Linking migration, reproduction and wellbeing: exploring the reproductive strategies of low-income rural-urban migrants in Vietnam (Vietnam) \\ January 2008 - June 2010 \\ Catherine Locke \\ UNIVERSITY OF EAST ANGLIA, UK \\ Focused on the reproductive strategies of low-income rural-urban migrants in Vietnam.}

Using life histories from Hanoi and Ho Chi Minh, the project built up a picture of the range of family strategies that poor men and women migrants used during their peak child-bearing and early child-rearing years. The findings of this project significantly extended the empirical evidence which international social and development policies relating to migration, reproduction and gender need to take into account.

\section{Livelihoods after land reform: the poverty impacts of land redistribution in southern Africa}

(Namibia, South Africa, Zimbabwe)

October 2006 - March 2010

Ben Cousins

UNIVERSITY OF THE WESTERN CAPE, SOUTH AFRICA Through case studies in South Africa, Zimbabwe and Namibia, this project explored to what extent land redistribution in southern Africa is achieving objectives of poverty reduction and livelihood improvement. It gathered empirical data on livelihoods impacts; explored what conditions including appropriate land transfer mechanisms, tenure arrangements, and post-settlement support - are likely to result in poverty reduction; interrogated what is meant by 'viable' land reform; and developed replicable methodologies for assessing impacts at different scales.

\section{Local governance, urban mobility, and poverty reduction. Lessons from Medellín, Colombia (Colombia)}

September 2010 - November 2012

Julio Davila

UNIVERSITY COLLEGE LONDON, UK

This project examined the links between mobility, poverty reduction, social inclusion, and urban integration. It conducted a critical assessment of a set of interventions fostered by the local government of Medellín, Colombia's second largest city, a central component of which was the introduction of two aerial cable-car lines linked to the city's mass-transit system. Also examined the transferability of aerial cable-car technology to cities with similar topographic, institutional, and socioeconomic conditions in Latin America and elsewhere. 


\section{Lone mothers in South Africa - the role of social security in respecting and protecting dignity \\ (South Africa)}

September 2011 - August 2014

Michael Noble

UNIVERSITY OF OXFORD, UK

This study explored lone mothers' experiences of social security in South Africa in terms of whether it protects and respects their dignity. The primary objectives were to understand how lone mothers interpret dignity in the context of their daily lives; how their lived experience of poverty and inequality impacts on their dignity; the extent to which they regard social grants as respecting and protecting their dignity; and how the experience of claiming social assistance intersects with their dignity.

\section{Making it happen - increasing access to diagnosis and treatment for tuberculosis} (Ethiopia)

March 2014 - March 2015

Luis Eduardo Cuevas

LIVERPOOL SCHOOL OF TROPICAL MEDICINE, UK One third of 8.7 million cases of tuberculosis (TB) occurring each year are missed by health services. In Ethiopia, TB is one of the major causes of adult death, affecting the lives of many people, and health service coverage is poor, resulting in low case detection. This project explored approaches to enhance TB case detection by addressing the barriers and bringing services closer to poor and vulnerable groups.

One third of 8.7 million cases of tuberculosis (TB) occurring each year are missed by health services. In Ethiopia, TB is one of the major causes of adult death, affecting the lives of many people, and health service coverage is poor, resulting in low case detection.
Making space for the poor: law, rights, regulation and street-trade in the 21st century (India, Senegal, South Africa, Tanzania) August 2010 - October 2013

Alison Brown

CARDIFF UNIVERSITY, UK

Explored the fragmented and plural regulatory environment facing street traders, and conflicts between formal and informal regulatory systems that deepen vulnerabilities for the working poor. It focused on four cities with different legal traditions: Dakar (Senegal), Dar es Salaam (Tanzania), Ahmedabad (India), and Durban (South Africa). The research found widespread politicisation of street trade, harassment, evictions and marginalisation of street traders, suggesting an urgent need for legal review and 'rights regimes' that respect the right to work.

\section{Marriage, power and wellbeing (Uganda) \\ May 2006 - September 2008 \\ Cecile Jackson \\ UNIVERSITY OF EAST ANGLIA, UK}

This research contributed to knowledge on the exercise of agency within marriage and the ways in which power is expressed, controlled, effective and thwarted in the everyday conduct of conjugality, and the trajectories of marriage, divorce, remarriage and non-marriage over the life course. It studied a rural area of eastern Uganda, dominated by the Bagisu, and used multiple methods, including survey data, ethnography, and the methods of experimental economics with married couples.

\section{Maximising the developmental impact of philanthropy: from theory to practice (Sri Lanka) March 2014 - January 2015 \\ Roderick Lennox Stirrat UNIVERSITY OF SUSSEX, UK \\ This project built upon earlier research into the potential role of charity and philanthropy}


to support development. The earlier research indicated a considerable demand for assistance in defining more sustainable and effective approaches to charitable and philanthropic activities amongst charitable organisations, the general public, and the corporate sector. This project utilised these findings to generate a more professional and effective approach amongst Sri Lankan philanthropic institutions.

\section{Measuring complex outcomes of environment} and development interventions

(Cambodia, Tanzania, Uganda)

December 2012 - March 2016

David Wilkie

WILDLIFE CONSERVATION SOCIETY, USA

Examined interventions designed to counter increasing environmental resource scarcity, caused by unsustainable use of biodiversity, deforestation, and degradation of ecosystem services. The project explored how poor

people's experience of change can be factored more directly into policy evaluation and formulation. Also delivered innovative ways to capture poor people's experienced wellbeing, enabling comparison with more established measurements of change, and building a more robust evidence base about what interventions work, how, and for whom.

\section{Menstruation and the cycle of poverty: does the provision of sanitary pads improve the attendance and educational outcomes of girls in school? \\ (Uganda)}

October 2013 - December 2014

\section{Catherine Dolan}

SCHOOL OF ORIENTAL AND AFRICAN STUDIES (SOAS), UK In many poor communities, menstruation is still often seen as an embarrassing, shameful, and dirty process. Such taboos around the topic mean many adolescent girls are unprepared for their periods and how to manage them. The research tested whether school attendance improved when girls were given washable, reusable sanitary pads and were provided with adolescent reproductive health education.
Mining, social networks and rural livelihoods in Bangladesh

(Bangladesh)

January 2008 - March 2011

Katy Jane Gardner

UNIVERSITY OF SUSSEX, UK

This project explored the impact of mining on rural livelihoods in Bangladesh through two case studies. The first of these involved the extraction of natural gas in Sylhet, an area where long-standing transnational migration to the UK means that social networks, and the social protection which they provide for the poor, take on an international dimension.

In the second case, national and local resistance movements to the extraction of coal in Dinajpur were the main focus.

\section{Mobile payment systems to reduce rural water risks in Africa}

(Kenya)

October 2015 - March 2017

Robert Adrian Hope

UNIVERSITY OF OXFORD, UK

This research project contributed to knowledge on improved handpump management by insuring payment risks. Like insurance products that pool risk of unanticipated but costly events, the study applied the same approach to community handpumps in rural Kenya by bringing communities together in a shared financial model that reduces costs by sharing them amongst hundreds of handpumps. The project made science and policy advances in knowledge on information, institutional and financial systems.

\section{Multidimensional poverty: enriching methodologies of measurement and policy analysis}

(Global)

July 2011 - June 2014

Sabina Alkire

UNIVERSITY OF OXFORD, UK

This project developed new methodologies related to multidimensional poverty measurement and analysis corresponding 
to: weights, trade-offs, and policy incentives in multidimensional poverty measures; multidimensional poverty dynamics; and multidimensional poverty and welfare economics.

\section{Narratives of violence: the impact of internal} displacement on violence against women in

\section{Nepal and Myanmar}

(Myanmar, Nepal)

December 2017 - May 2019

Tamsin Bradley

UNIVERSITY OF PORTSMOUTH, UK

This research will document explanations from women in Nepal and Myanmar of how displacement has affected gendered relations and women's resultant experiences of violence. This will involve collecting unstructured narratives and quantitative data from women who have experienced rural-urban displacement. The research aims to bring more complex and nuanced insight into displaced women's experiences.

\section{Negotiating conflict: environmental violence,} economic development and the everyday

\section{practices of islanders}

(Maldives)

October 2017 - September 2019

Uma Kothari

UNIVERSITY OF MANCHESTER, UK

Research addressing conflict and conflict resolution in regards to 'environmental violence' can overlook what is significant to ordinary people on a day-to-day basis. Focusing on the Maldives, a country representative of the economic and environmental challenges facing small island developing states. Insights will contribute to ongoing conflict resolution and poverty reduction efforts in the country, and beyond, by emphasising the importance of engaging with people's everyday perceptions and experiences of environmental violence in developing country contexts.

\section{New mobile citizens and waterpoint sustainability in rural Africa \\ (Kenya)}

September 2012 - August 2015
Robert Adrian Hope

UNIVERSITY OF OXFORD, UK

This research project contributed to

knowledge on how Africa's innovation in mobile technology could form a key platform to resolve the continent's problem of safe and reliable water access. The project tested at scale an innovative new device designed and piloted by Oxford University which has the potential to capture and share data from remote and dispersed regions seamlessly, and instantaneously opens up new and exciting possibilities for change.

\section{New norms and forms of development:} brokerage in maternal and child health service development and delivery in Nepal and Malawi

(Malawi, Nepal)

March 2014 - October 2016

lan Harper

UNIVERSITY OF EDINBURGH, UK

Through its focus on the role and functions of different types of institutions and professionals who broker health sector development projects and programmes, the research explored the nature of mediation and translation involved in the process, and the difference these actors make in meeting the global health development objectives.

\section{Parliamentary effectiveness: public engagement for poverty reduction in Bangladesh and Ethiopia}

(Bangladesh, Ethiopia)

February 2014 - December 2017

Emma Crewe

SCHOOL OF ORIENTAL AND AFRICAN STUDIES (SOAS), UK

The work of parliament and parliamentarians is changing within most nations: they grow stronger as many countries develop better structures and processes, but weaker in the sense that many citizens become disillusioned with their political leaders. This research specifically explored the relationship between parliament, parliamentarians and individuals and groups within the public. It explored: What makes MPs 
effective? What roles do they play in poverty reduction and the promoting of equality? How do we measure it and who decides?

\section{Pathways out of poverty for Burkina Faso's reservoir-dependent communities \\ (Burkina Faso)}

October 2017 - March 2019

Marlène Elias

BIOVERSITY INTERNATIONAL, ITALY

This project will convene stakeholders around two reservoirs in Boulgou province, Burkina Faso, through 'Innovation Platforms' which provide differentiated stakeholders with conflicts of interests related to reservoirs with spaces for face-to-face learning, exchange, and negotiation. The research will fill gaps in knowledge regarding factors and approaches that enable the resolution of conflicts related to the management of common pool resources and the development of participatory monitoring systems.

Political settlement in Somaliland: a gendered perspective

(Somaliland)

July 2015 - January 2017

Michael Walls

UNIVERSITY COLLEGE LONDON, UK

This project developed a gender-aware analysis of the political settlement in Somaliland and explored ways in which policy and interventions could contribute to more effective and equitable development and increased stability as well as increase women's political participation. This included an analysis of how gender identities are perceived and how they influence sociopolitical participation and violence against women and girls, and how this has contributed to or undermined a stable, inclusive post-conflict political settlement.

\section{Poverty alleviation and women refugees in the Middle East: empowerment through grass- roots micro-entrepreneurship? (Jordan, Lebanon, Turkey) July 2016 - June 2019}

Haia Al-Dajani

UNIVERSITY OF PLYMOUTH, UK

This project explores the effectiveness and impact of the available pathways for support and advice for displaced and refugee women in Jordan, Lebanon and Turkey. It will analyse the extent to which entrepreneurship is a sustainable conduit for poverty alleviation and empowerment in socio-politically volatile circumstances. It will generate longitudinal empirical evidence and develop theoretical frameworks regarding entrepreneurship, empowerment, gender and poverty alleviation in a context of displacement whilst generating impact through informed models of policy and practice.

\section{Poverty alleviation in the wake of typhoon Yolanda}

\section{(Philippines)}

March 2015 - June 2018

Pauline Eadie

UNIVERSITY OF NOTTINGHAM, UK

This project monitored the effectiveness of the typhoon Yolanda relief efforts in the Philippines in relation to building sustainable routes out of poverty. It focused on urban population risk, vulnerability to disasters, and resilience in the aftermath of these shocks. Lessons learned are highly relevant to post-disaster reconstruction efforts in low-income countries, specifically within densely populated urban areas.

\section{Poverty and maternal health in Ghana: a spatial analysis of exclusion from care (Ghana)}

July 2008 - January 2011

Zoe Matthews

UNIVERSITY OF SOUTHAMPTON, UK

This project quantified the spatial links between poverty and poor utilisation of maternal health services in Ghana. It built on previous work in a range of African countries, which showed that individual and community characteristics alone do not go far towards explaining service use at childbirth, especially in West African countries. 


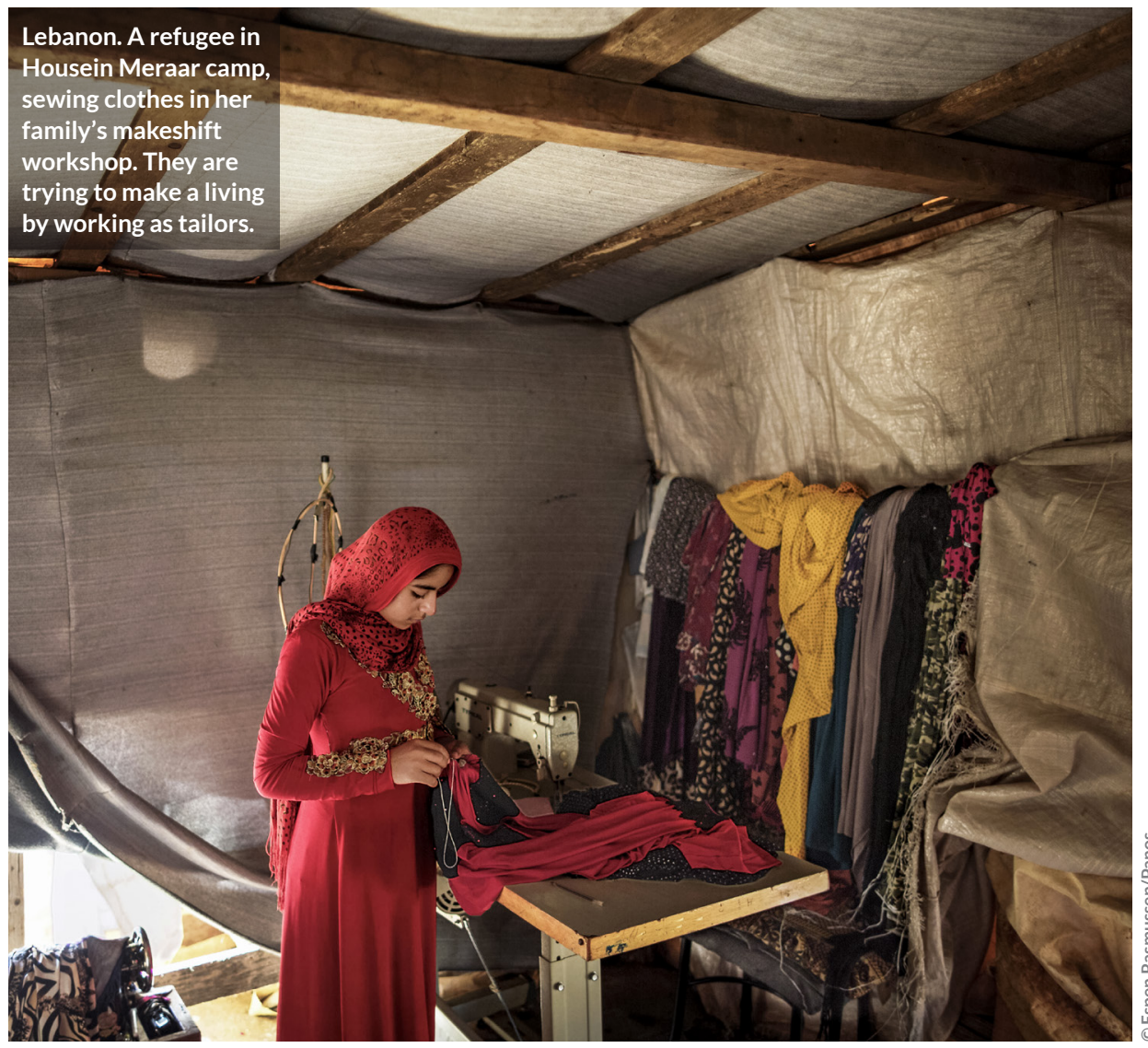

Poverty reduction and regional integration: a comparative analysis of SADC and UNASUR

\section{health policies}

(Bolivia, Paraguay, Swaziland, Zambia)

March 2014 - December 2015

Nicola Yeates

OPEN UNIVERSITY, UK

The project examined the scope for enhancing Southern multilateral regional organisations contributions to poverty reduction through regional health policy. It conducted a comparative analysis of SADC and UNASUR regional agendas and ambitions, regional programmes of action and regional processes of policy development in relation to access to health care and medicines.
Pregnancy termination trajectories in Zambia: maximising research impact (Zambia) June 2014 - August 2015

Ernestina Elizabeth Coast

LONDON SCHOOL OF ECONOMICS AND POLITICAL SCIENCE (LSE), UK

Unsafe abortion is a significant preventable cause of maternal mortality and morbidity. In Zambia it remains a major challenge, despite legalised abortion and a favourable policy framework. This project sought to maximise the impact of research that has investigated the socioeconomic costs of unsafe and safe abortion for women, their households and the Zambian health system. 
Pregnancy termination trajectories in Zambia: the socioeconomic costs

\section{(Zambia)}

December 2011 - November 2014

Ernestina Elizabeth Coast

LONDON SCHOOL OF ECONOMICS AND POLITICAL SCIENCE (LSE), UK

Unsafe abortion is a significant, preventable cause of maternal mortality and morbidity and is both a cause and a consequence of poverty.

This research explored how investment in safe abortion services impacts on the socioeconomic conditions of women and their households, and the implications for policymaking and service provision in Zambia.

\section{Proposal to conceptually integrate social determinants of health research and capabilities approach to development and}

\section{social justice}

\section{(El Salvador, Peru)}

February 2008 - September 2010

Michael Gideon Marmot

UNIVERSITY COLLEGE LONDON, UK

This interdisciplinary project carried out conceptual groundwork towards constructing a theory of health causation and distribution that spans poor and rich countries, as well as one that can account for biology, individual behaviour, material agents, and social conditions. Three main research areas were examined: the philosophy of social epidemiology; conceptualising human health as a capability; and integrating social determinants research and capabilities theory.

\section{Religion and childhood death in India (India)}

May 2007 - October 2009

Sonia Bhalotra

UNIVERSITY OF BRISTOL, UK

This research analysed why Indian Muslims exhibit substantially higher child survival rates than Indian Hindus. The project was motivated by this puzzle because Muslims have, on average, lower socioeconomic status, higher fertility, shorter birth-spacing, lower autonomy amongst women, and are a minority group in India that, in principle, might live in areas that have poorer public provision. The results of the study contribute to a literature that debates the importance of socioeconomic status in determining health and survival.

\section{Resilience in West African frontier communities} (Guinea, Mali, Senegal)

December 2017 - May 2020

Marie Rodet

SCHOOL OF ORIENTALAND AFRICAN STUDIES (SOAS), UK

This project aims to generate a better understanding of resilience strategies and local knowledge as developed in frontier communities of southern Senegal, western Mali and eastern Guinea to respond to ongoing ecological, economic and political stresses. By looking at mobility, multilingualism, and social stratification reconfigurations as interrelated resilience strategies, the project aims at improving development initiatives in the region.

\section{Resilience policymaking in Nepal: giving voice to communities}

(Nepal)

September 2017 - September 2018

Simon Rushton

UNIVERSITY OF SHEFFIELD, UK

This project utilised participatory video to address the gap that exists in Nepal between national-level resilience policymaking (undertaken with the support of international donors and experts) and community-level perceptions and expectations. In so doing, the project gave those most affected by the overlapping challenges of poverty, conflict and environmental change a powerful way to engage with, and potentially influence, high-level policymakers.

\section{Resources, greenhouse gas emissions, technology and work in production and distribution systems: rice in India (India)}

October 2011 - June 2014

Barbara Harriss-White

UNIVERSITY OF OXFORD, UK

Informal economies are neglected in debates about climate change and the long-awaited materials revolution. Uniting lifecycle analysis 


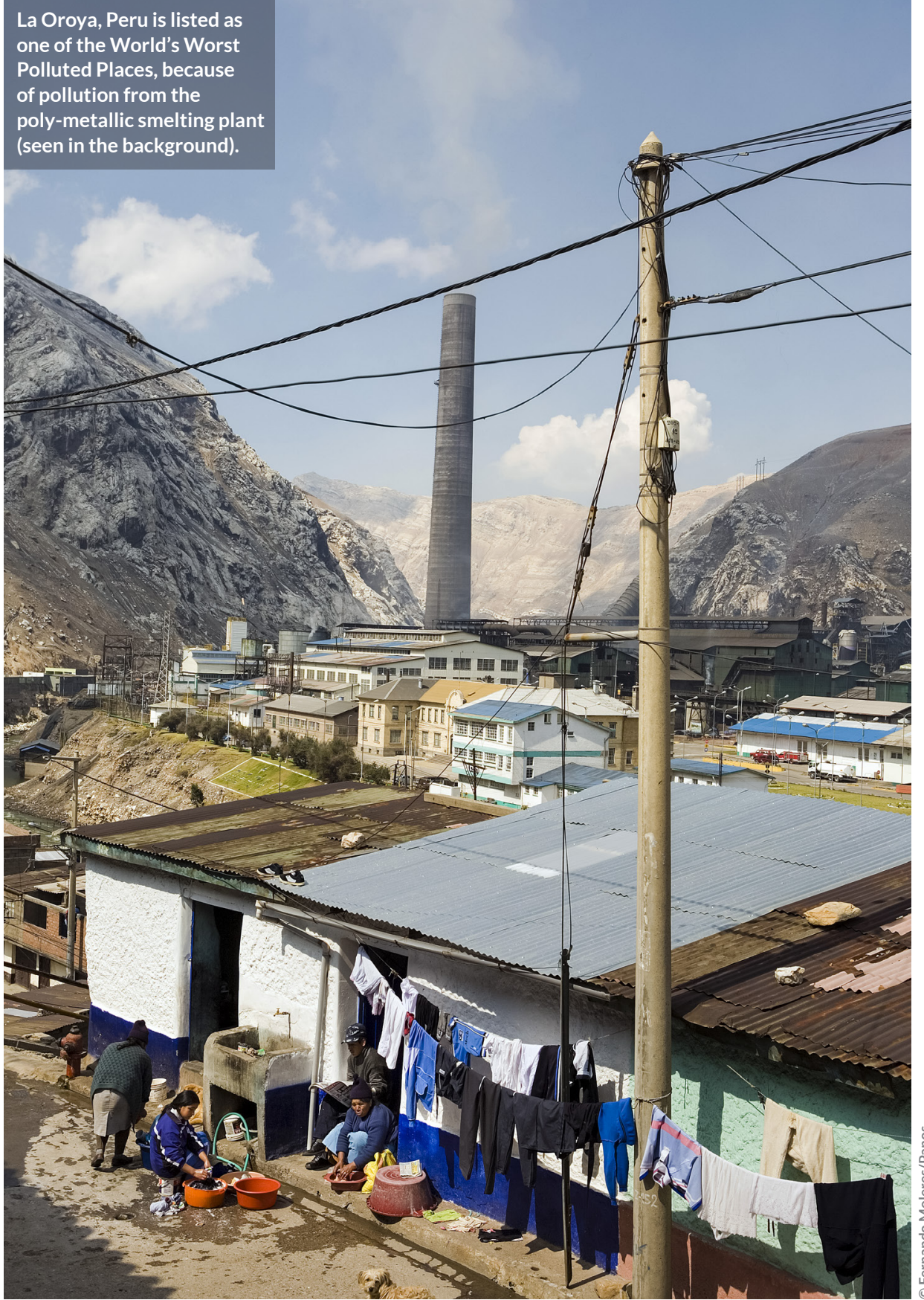


(from environmental science) with value chain/production system analysis (from management science and economics) and decent work criteria (from labour studies), this transdisciplinary project explored how capital, technology and labour are combined to produce commodities and greenhouse gases (GHGs). Multi-criteria analysis explored the costs and incommensurable trade-offs of technology lowering GHGs and improving livelihoods.

\section{Rethinking environment and development in} an era of global norms: an exploration of forests and water in Nepal, Sudan and Uganda (Nepal, Sudan, Uganda)

October 2013 - March 2015

Thomas Sikor

UNIVERSITY OF EAST ANGLIA, UK

Responding to the emergence of global norms intended to reconcile natural resource management with poverty alleviation, this research focused on the cross-scale relationships between

local environmental struggles, higher-level mobilisations for environmental justice and global norms through the lens of environmental justice. Struggles over justice are an integral element of environmental politics across scales, connecting local struggles to mobilisations at (inter)national levels as well as the conceptions informing global norms - and causing frictions between them.

\section{Rethinking environment and development in an era of global norms: exploring international politics of justice on carbon forestry and \\ hydropower}

(Nepal, Sudan, Uganda)

January 2016 - November 2017

Mark Zeitoun

UNIVERSITY OF EAST ANGLIA, UK

This research employed an environmental justice lens to examine the effects of global environmental norms intended to reconcile natural resource management with poverty alleviation, through explorations of forests and water. These norms include the social safeguards in global conventions and the human rightsbased rulings of international courts, and have the potential to transform development practice in the future, so long as they effectively support poor people's claims on natural resources and rights to sustainable livelihoods.

\section{Safe and sustainable cities: human security, migration, and wellbeing}

(Bangladesh)

October 2017 - March 2019

Neil Adger

UNIVERSITY OF EXETER, UK

Incorporating migrant perspectives and sources of innovation into urban planning to build safer and more sustainable cities, this project represents frontier research in framing new migrant populations as sources of innovation and sustainability, and in using multiple methods to incorporate new migrant population perspectives into sustainable places.

The research involves planners in Chittagong in coastal Bangladesh and its new migrant populations, including some displaced because of environmental hazards, and ethnic minority groups.

\section{Security on the move: everyday security of IDPs in rapidly growing Somali cities}

(Somalia)

October 2017 - March 2019

Jutta Bakonyi

DURHAM UNIVERSITY, UK

The interplay between violent conflict and droughts is described as one of the main drivers of internal displacement in Somalia, but rapid inmigration to cities further increases pressures on the urban and rural environment. Focusing on the

As more people connect to social media in Africa, their expectations for real-time information are changing, posing new challenges concerning the rapid flow of (mis) information, whilst also creating opportunities for an improved cooperative relationship in enhancing community safety. 
capacities of internally displaced people to cope with the effects of violence and displacement and to mitigate vulnerability, this research project addresses the nexus of poverty, environmental sustainability, and conflict in Somalia.

\section{Shame, social exclusion and the effectiveness of anti-poverty programmes: a study in seven countries}

(China, Germany, Norway, Pakistan, South Korea, Uganda, United Kingdom)

August 2010 - December 2012

Robert LLoyd Walker

UNIVERSITY OF OXFORD, UK

Shame is believed to reduce a person's agency, the capacity to act constructively, and to increase social exclusion which, in turn, curtails economic development. This research explored cultural conceptions of poverty and shame; learnt from people with direct experience of poverty; examined the role of the public in shaming poor people; and undertook a policy analysis of social assistance and other anti-poverty programmes.

\section{Shifting in/equality dynamics in Ethiopia: from research to application (SIDERA)}

\section{(Ethiopia)}

December 2017 - May 2019

Mercy Fekadu Mulugeta

INSTITUTE FOR PEACE AND SECURITY STUDIES, ETHIOPIA

Rapid changes in the natural, social, and economic environment are occurring in Ethiopia's Lower Omo Valley, as part of a stateled development vision of repositioning the region as a major sugar exporter. This research explores the spatial and temporal availability of and access to natural resources in the region; how the changing resources are affecting conflict dynamics in the region; and how these changes are influencing relations of material in/equality.

\section{SMS Africa: social media and security in Africa (Kenya, Sierra Leone, Tanzania) \\ July 2015 - July 2020 \\ Thomas Stephen Molony \\ UNIVERSITY OF EDINBURGH, UK \\ The project examines the role social media plays in documenting and driving (in)security in East and}

West Africa, and explores how the risks and impact of violence and instability that affect the poor can be reduced. As more people connect to social media in Africa, their expectations for real-time information are changing, posing new challenges concerning the rapid flow of (mis)information, whilst also creating opportunities for an improved cooperative relationship in enhancing community safety.

\section{Social cash transfers, generational relations} and youth poverty trajectories in rural Lesotho

\section{and Malawi}

(Lesotho, Malawi)

October 2015 - May 2019

Nicola Ansell

BRUNEL UNIVERSITY, UK

This project explores the factors that shape the pathways into and out of poverty, and people's experience of these, and examines how policy can create sustained routes out of extreme poverty in ways that can be replicated and scaled up. It contrasts social cash transfers (SCTs) in two countries in the past decade: Lesotho (social pensions and child grants) and Malawi (SCTs to ultra-poor labour-constrained households).

\section{Social movements and poverty}

\section{(Peru, South Africa)}

July 2007 - January 2010

Anthony J Bebbington

UNIVERSITY OF MANCHESTER, UK

The collective action of social movements is often said to be one of the most effective strategies that the poor can use in addressing their poverty, but little is known about the number, diversity and extent of such movements, or their importance in poverty reduction. Focusing on Peru and South Africa, this research addressed how and why movements adopt particular strategies in their relationships with the state, their influence on poverty reduction and their political contexts.

Social protection and disability: policy lessons from Vietnam

(Vietnam)

October 2012 - September 2014

Nora Groce

UNIVERSITY COLLEGE LONDON, UK 
People with disabilities (PWDs) represent a disproportionately high number of the world's poor. PWDs are increasingly being mainstreamed into government social protection programmes in low- and middle-income countries. This research evaluated the efficacy of two government social protection programmes for PWDs in Vietnam, including a cash transfer programme and a free health insurance programme.

\section{Socioeconomic inequalities and the MDGs:}

\section{building evidence to support equitable} improvement in maternal and newborn health

\section{in Asia and Africa}

(Bangladesh, India, Malawi, Nepal)

July 2011 - September 2015

Antonia Jannetje (Tanja) Houweling

UNIVERSITY COLLEGE LONDON, UK

This project generated evidence on: how socioeconomic inequalities translate into inequalities in newborn and maternal mortality;

how to address the exclusion of poor and otherwise disadvantaged groups from efforts to achieve the MDGs; and how to reduce socioeconomic inequalities in maternal and newborn mortality.

\section{Stigma and discrimination associated with tuberculosis (TB) in Asia}

(Bangladesh, Nepal, Pakistan)

May 2007 - May 2009

James Nicholas Newell

UNIVERSITY OF LEEDS, UK

This project produced strategies to reduce stigma and discrimination around tuberculosis

(TB). It explored how to make it easier for TB patients, especially poor TB patients, to receive proper diagnosis and treatment.

\section{Strengthening ODFL systems to increase education access and attainment for young people in high HIV prevalence SADC countries (Lesotho, Malawi) April 2007 - July 2010 \\ Pat Judith Pridmore INSTITUTE OF EDUCATION, UK}

\section{Health inequities - the unfair and avoidable differences in health arising from social, economic or political factors, and which disadvantage the poor and marginalised - are trapping millions of people in poverty.}

This study aimed to increase access to education and learning for young people living in high HIV prevalence areas in Malawi and Lesotho, by developing a new, more flexible model of education that used open, distance and flexible learning (ODFL) to complement and enrich conventional schooling.

\section{Student performance in national}

examinations: the dynamics of language in

school achievement

(Tanzania)

July 2007 - December 2010

Pauline Rea-Dickins

UNIVERSITY OF BRISTOL, UK

This project focused on three curriculum areas: Science, Mathematics, and English. The research aimed to develop insights into the extent to which language factors contribute to poor examination achievement, and to identify factors that will raise the quality of examining processes and enhance students' potential to demonstrate fully their conceptual understandings.

\section{Supporting the social mobility of trapped populations in very poor urban areas (Bangladesh, Somaliland, Sri Lanka, Zimbabwe)}

September 2016 - August 2018

Michael Collyer

UNIVERSITY OF SUSSEX, UK

This project investigated when migration from rural to urban areas becomes a pathway into poverty and how policy can support ruralurban migrants to access urban opportunities 
and escape from poverty. It considered under what circumstances rural-urban migration presents an opportunity for poor people and what factors contribute to them becoming 'trapped'; the relationship between physical and socioeconomic mobility; and the attitudes of city government, community organisations, police, NGOs and international organisations.

\section{'Tangled in their own (safety)-nets'?}

Resilience, adaptability, and transformability of fishing communities in the face of the

\section{world fisheries crisis}

\section{(Fiji, Ghana, Sri Lanka, Vietnam) \\ October 2012 - July 2015 \\ Christophe Bene \\ INSTITUTE OF DEVELOPMENT STUDIES (IDS), UK \\ This project used resilience thinking and wellbeing research to generate empirical qualitative and quantitative analyses and provide a policy-relevant answer to the question: how can policy reforms aimed at reducing fishing efforts (in order to restore the sustainability of the world fisheries) be implemented without causing millions of resource-poor people to fall deeper into deprivation and food insecurity? The research thus aimed to reconcile inclusive growth with resource conservation.}

\section{Temporary migration and economic}

\section{development: the triple-win policy vision applied to North Africa \\ (Egypt, Morocco)}

February 2012 - October 2014

Jackline Wahba

UNIVERSITY OF SOUTHAMPTON, UK

This project enlarged the evidence base of the triple-win policy vision of temporary migration, by focusing on the return migrants. The research highlighted the determinants and impacts of return migration by focusing on two North African countries, Egypt and Morocco, which share similar domestic labour market problems such as high youth unemployment and lack of jobs, but have different migration profiles in terms of gender, education and destination.
The accountability politics of reducing health inequities: learning from Brazil and Mozambique

(Brazil, Mozambique)

April 2016 - December 2018

Alexander Shankland

INSTITUTE OF DEVELOPMENT STUDIES (IDS), UK

Health inequities - the unfair and avoidable differences in health arising from social, economic or political factors, and which disadvantage the poor and marginalised - are trapping millions of people in poverty. This project compares the dimensions of accountability politics and health inequalities across Brazil and Mozambique and between different areas within each country. This project is also known as: the Unequal Voices project.

\section{The design and evaluation of a mobile learning intervention for the training and supervision of community health workers \\ (Kenya)}

November 2014 - September 2015

Niall Winters

UNIVERSITY OF OXFORD, UK

Researchers worked closely with community health workers, and their supervisors, to collaboratively design, develop, implement and evaluate a mobile learning intervention. This provided a mobile portfolio of their practice, easily accessible reference material, and the ability to share practice-related questions and resources with colleagues through activities which promoted peer learning and reflection.

\section{The development of migrant villages under China's rapid urbanisation: implications for poverty and slum policies}

(China)

June 2010 - September 2012

Fulong Wu

CARDIFF UNIVERSITY, UK

The project investigated the dynamics of migrant village formation, examining redevelopment practices and policies, and identifying the scope for progressive upgrading as an alternative approach. Fifteen migrant villages were sampled, to identify the housing tenure, socioeconomic 
profiles, landlords' self-construction tactics, migrants' coping strategies, and existing and new institutions as appropriate vehicles for in-situ redevelopment. The project informed Chinese policymakers and provided learning feedback to the wider international development community.

\section{The economic and social consequences of} armed conflict in Colombia: evidence for designing effective policies in conflict and post-conflict regions

(Colombia)

October 2010 - October 2012

Ana Maria Ibáñez

UNIVERSITY OF THE ANDES, COLOMBIA

Colombia, a country that has endured civil conflict for over 40 years, provided an interesting opportunity to understand the microeconomic impacts of conflict. The research examined the effect that armed conflict has had on a range of entrepreneurial decisions in the manufacturing sector; the effects that armed conflict has had health outcomes caused by the aerial spraying of herbicides to destroy illicit crops.

\author{
The economic and social effects of care \\ dependence in later life \\ (China, Mexico, Nigeria, Peru) \\ September 2011 - March 2014 \\ Martin James Prince \\ KING'S COLLEGE LONDON, UK \\ Households where an older person had \\ developed needs for care (incident care \\ households) were compared with those with \\ older residents with long-standing needs for \\ care (chronic dependence) and with no needs for \\ care (control households). Detailed household \\ interviews assessed various factors, including \\ changes attributable to the onset/intensification \\ of care-dependence. Detailed case studies \\ elucidated the pathways involved.
}

\section{The Gansu survey of children and families, wave 3} (China)

May 2007 - December 2010

Emily Carroll Hannum

UNIVERSITY OF PENNSYLVANIA, USA

The Gansu Survey of Children and Families was a longitudinal study of poverty, education, health, and economic mobility among children and youth

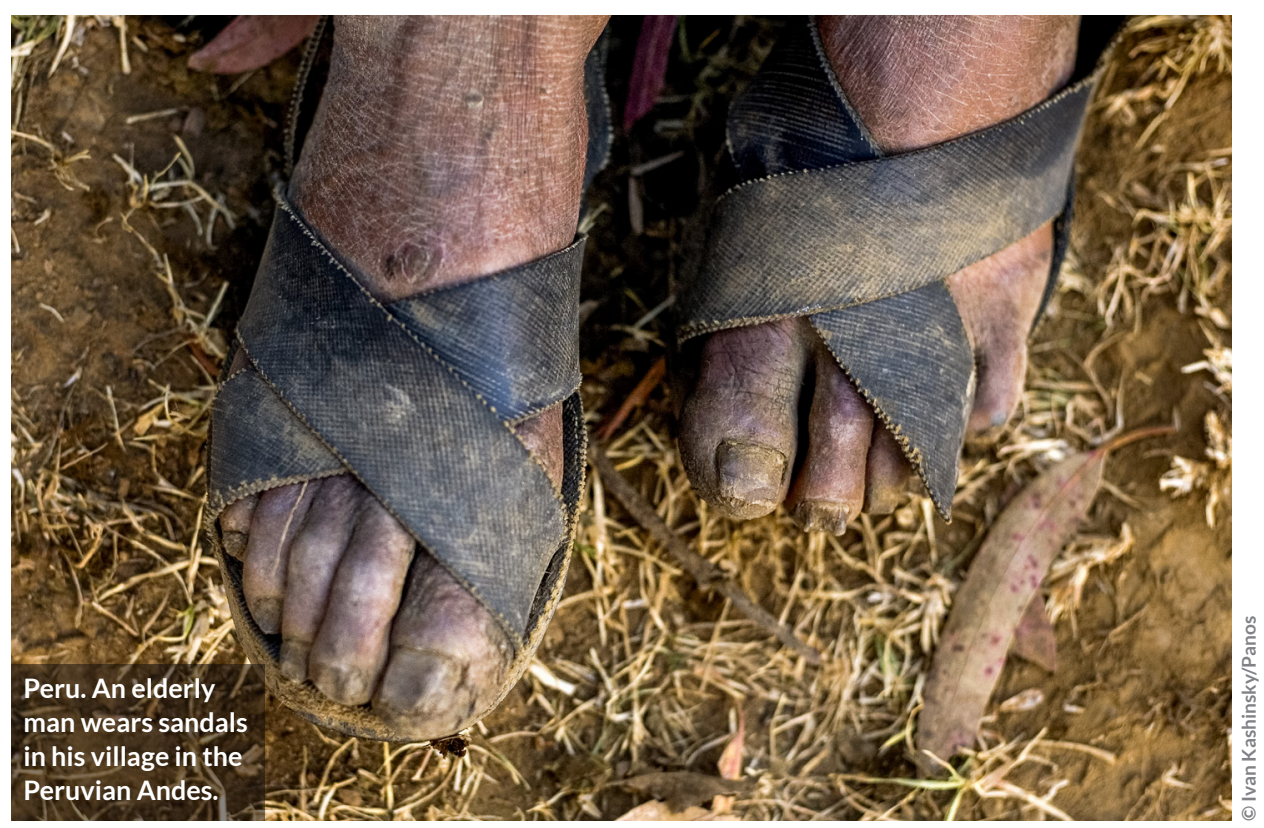


in rural northwest China which began in 2000.

This research undertook interviews in 2008, and looked at the impacts of childhood nutrition and health on subsequent education; psychological wellbeing; the decision to stay in school or enter the workforce; and the labour productivity of young adults.

\section{The identification and nurturing of high ability} students in the slums of Dar es Salaam, Tanzania

(Tanzania)

December 2013 - June 2015

Pauline Dixon

NEWCASTLE UNIVERSITY, UK

This project focused on the identification

process for high ability children attending schools in the slums of Dar es Salaam, Tanzania. The identification process was observed to find out whether it included bias towards a particular gender or cultural norms.

\section{The impact of mobile phones on young} people's lives and life chances in sub-Saharan Africa: a three country study to inform policy and practice

(Ghana, Malawi, South Africa)

August 2012 - December 2015

Gina Porter

DURHAM UNIVERSITY, UK

This project explored how the rapid expansion of mobile phone usage impacts on young lives, and examined how policymakers can support the positive aspects of this change, whilst constraining the negative elements of mobile phone usage.

\section{The influence of DFID-sponsored state}

\section{building-oriented research on British policy in} fragile, post-conflict environments

(Afghanistan, Nepal, Sierra Leone)

January 2011 - December 2013

Sultan Barakat

UNIVERSITY OF YORK, UK

This project addressed the following research question: How has state building-oriented research sponsored by DFID influenced and interacted with UK governmental policies targeting fragile, post-conflict environments?
Researchers and policymakers were engaged to establish explanatory narratives for the 'returns' identified, and investigators 'forward-tracked' the dissemination, use, and uptake of recently completed DFID-sponsored studies, physically mapping research transmission applying a 'payback model', and determining what factors increase or impede its influence.

\section{The intra-household allocation of resources:} cross-cultural tests, methodological innovations and policy implications (Burkina Faso, Ethiopia, India, Nigeria) June 2007 - January 2008

Alistair Munro

ROYAL HOLLOWAY, UNIVERSITY OF LONDON, UK We know that gender matters for the incidence of poverty, ignorance and disease. What is not understood so clearly, however, are the critical factors for determining resource allocation within the home. Using experiments, surveys and ethnographic interviews across selected countries, this research tested theories of how resources get allocated within households, and developed a clearer picture on how efficiency and perceptions of fairness determine household allocation.

\section{The long run history of economic inequality (Global)}

January 2012 - December 2014

Facundo Alvaredo

PARISSCHOOL OF ECONOMICS, FRANCE

This research covered four themes: the assembly and analysis of historical evidence from fiscal records on the long-run development of economic inequality; cross-country comparisons, drawing on evidence globally; the analysis of sources of economic advantage, in order to understand the drivers of inequality; and the long-run trend in the distribution of wealth and its transmission through inheritance.

\section{resilience in Bangladesh \\ (Bangladesh) \\ January 2007 - December 2008 \\ Andrew Elvin Collins \\ NORTHUMBRIA UNIVERSITY, UK}

The meaning of health security for disaster 
This project assessed how health influences vulnerability to major disaster events. It generated knowledge on health security as part of disaster risk reduction and on its role in sustainable livelihoods.

The promises of fibre-optic broadband: a pipeline for economic development in East Africa

(Kenya, Rwanda)

September 2011 - August 2014

Mark Graham

UNIVERSITY OF OXFORD, UK

Employing case-studies in Kenya and Rwanda,

this project examined the expectations and potentials of broadband internet and compared those expectations to on-the-ground effects that broadband connectivity has had in three economic sectors: tea production, ecotourism, and business process outsourcing. Surveys and indepth interviews were conducted at 240 selected small and medium-sized firms to study the existing communications ecology, and any potential effects of information and communication technologies and broadband connectivity.

\section{The social conditions for successful community mobilisation: learning from sex worker-led}

\section{projects in India}

(India)

March 2007 - May 2010

Flora Cornish

GLASGOW CALEDONIAN UNIVERSITY, UK

This research examined two uniquely successful community mobilisation projects led by sex workers in India, with the aim of understanding the social conditions that support effective grassroots development. The project investigated

The project draws on [....] the 'pathways approach' [...] to understand the complex pathways into and out of poverty, directing attention to poor people's collective capacity to bring about transformative change. the role of three key sets of stakeholders: those who had significance for the projects' public reputations (journalists, celebrities), practical, day-to-day functioning (police, local leaders), and strategic environment (politicians, government officers, funders).

\section{Towards a relational approach to agency for} mapping pathways into and out of poverty

(India, Kenya)

October 2016 - March 2019

Saurabh Arora

UNIVERSITY OF SUSSEX, UK

This project aims to develop the concepts and methods of an innovative 'relational agency pathways approach'. It draws on theories from science, technology and society studies and the 'pathways approach' to poverty reduction and social justice, which emphasise interactions between social, technological and environmental change, in order to understand the complex pathways into and out of poverty, directing attention to poor people's collective capacity to bring about transformative change.

\section{Tracing pharmaceuticals in South Asia: regulation, distribution and consumption} (India, Nepal)

September 2006 - December 2009

Roger Jeffery

UNIVERSITY OF EDINBURGH, UK

A multidisciplinary project which combined anthropological fieldwork with archival and interview-based research to investigate the conditions that make possible continuing inappropriate use of medicines in South Asia. It contributed to greater understanding of processes that lead to iatrogenic disorders (those induced unintentionally by a physician's diagnosis) for poor people, and offered improved understanding for the development of policy in these fields.

\section{Trade liberalisation, job reallocation and poverty: employment and earning losses after worker displacement \\ (Colombia) \\ October 2008 - April 2010 \\ Maurice Kugler \\ HARVARD UNIVERSITY, USA}




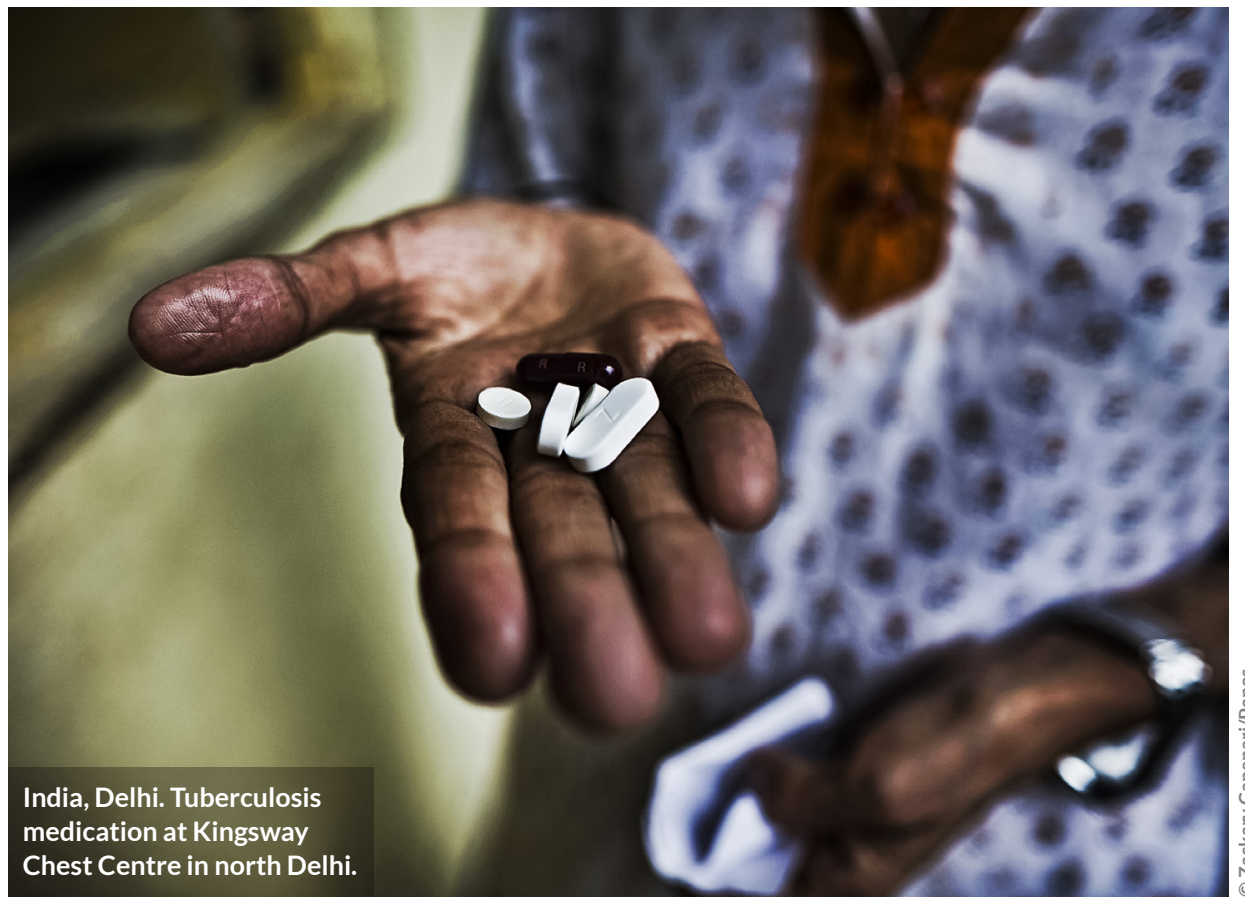

This project analysed costs that trade liberalisation imposed on workers in Colombia, with particular attention to effects on those earning relatively low wages. The Colombian experience of market reform, including trade liberalisation, typifies policies increasing openness to international trade, which have been pervasive in developing countries. The study provided lessons on policies that developing countries facing globalisation can implement to reduce the risks of poverty associated with lengthy jobless spells for unskilled workers.

\section{Transforming livelihoods: work, migration and} poverty in the Tiruppur garment cluster, India (India)

July 2008 - December 2010

Geert Raymond De Neve

UNIVERSITY OF SUSSEX, UK

The research used an interdisciplinary approach to critically examine changing livelihood strategies of both rural and urban populations affected by export industries, with field research conducted in and around Tiruppur, a major garment manufacturing and export town in South India. The project studied linkages between urban industrial development and changing rural hinterlands, with specific reference to poverty and livelihoods, socioeconomic mobility, and patterns of inequality.

\section{Tropical forests in poverty alleviation: from} household data to global-comparative analysis (Bangladesh, Cameroon, China, Ethiopia, India, Indonesia, Nepal, Pakistan, Uganda)

January 2008 - June 2011

Sven Wunder

CENTER FOR INTERNATIONAL FORESTRY RESEARCH (CIFOR), INDONESIA

The research highlighted the role of forests and environmental income in preventing and reducing rural poverty, looking at forests as a crucial part of the livelihoods of hundreds of millions of poor people worldwide. The project assessed whether certain types of forest-tenure 
and management regimes are more favourable than others, and under what conditions increased integration into forest-product markets can help.

Turning livelihoods to rubbish? Assessing the impacts of formalization and technologization of waste management on the urban poor (Ghana, South Africa, Uganda)

November 2015 - February 2019

Erik Achille Swyngedouw

UNIVERSITY OF MANCHESTER, UK

Waste reuse and recycling has become increasingly important to livelihoods, particularly in the global South. This research seeks to understand competing claims over what waste is, who should benefit from its management, and how decisions are made to allocate costs and benefits. It examines how changing political and institutional conditions shape different actors' abilities to garner benefits from waste and achieve sustainable pathways out of poverty.

\section{Understanding and supporting sustained} pathways out of extreme poverty and deprivation (Ethiopia, Rwanda, Tanzania)

July 2015 - February 2018

Andrew Shepherd

OVERSEAS DEVELOPMENT INSTITUTE (ODI), UK

This project concentrated on achieving a better understanding of how escapes from extreme poverty and deprivation can be sustained over time. It combined the analysis of quantitative data with a time dimension (panel surveys), the collection of life histories and face-to-face interviews and group discussions with policymakers and key informants at the local level.

\section{Understanding external determinants of the effectiveness of cash conditional transfers (Brazil, Cambodia, Honduras, Mexico) June 2010 - November 2013 \\ Christian Van Stolk \\ RAND EUROPE COMMUNITY INTEREST COMPANY, UK \\ This study reviewed empirical evidence from pilot programmes, household surveys}

Conditional cash transfers (CCTs) have had very heterogeneous impacts in different contexts, and understanding these institutional factors and household conditions can help determine the likelihood that CCTs will effectively alleviate poverty in the current economic environment.

and evaluations to identify institutional and household variables that have contributed to different impacts of conditional cash transfer (CCT) programmes. CCTs have had very heterogeneous impacts in different contexts, and understanding these institutional factors and household conditions can help determine the likelihood that CCTs will effectively alleviate poverty in the current economic environment.

\section{Understanding resilience in later life in a} low-resource setting

(Kenya)

October 2012 - July 2015

Maria Evandrou

UNIVERSITY OF SOUTHAMPTON, UK

This project adopted a mixed methods approach to improve understanding of how social capital, economic, and individual factors interact to enhance the wellbeing of older people living in the slums of Nairobi, Kenya. It combined in-depth qualitative research with quantitative analysis of unique panel data of 2,000 older people aged 50 and over living in two Nairobi slums, who were followed over time.

Understanding the political and institutional
conditions for effective poverty reduction for
persons with disabilities in Liberia
(Liberia)
April 2014 - August 2017


Maria Kett

LEONARD CHESHIRE DISABILITY, UK

This project explored what political and institutional conditions in Liberia are associated with effective poverty reduction and development, and what domestic and external actors can do to promote these conditions. It focused on the relationship between national and international institutions and actors to understand how the linkages and processes between state and society benefit persons with disabilities.

\section{Understanding the tipping point of urban conflict: violence, cities, and poverty}

\section{reduction in the developing world}

(Chile, India, Kenya, Timor-Leste)

September 2010 - August 2012

Caroline Moser

UNIVERSITY OF MANCHESTER, UK

This project re-thought conventional assumptions and offered new insights into the determinants of urban violence, identifying context-specific circumstances under which everyday urban conflict becomes violent. It tested a key hypothesis that urban conflict 'tips' into overt violence principally as a result of qualitatively-specific 'violence chains', and identified entry points to break linkages in these chains and foster new violence-reduction strategies, both within poor urban communities and at the metropolitan level.

\section{Urban growth and poverty in mining Africa} (Angola, Ghana, Tanzania)

October 2010 - June 2013

Deborah Fahy Bryceson

UNIVERSITY OF GLASGOW, UK

This study focused on the economic, social and cultural change associated with rapid and/ or erratic rates of urban growth propelled by mining expansion in three contrasting countries: Angola (diamonds), Ghana (gold), and Tanzania (gold/diamonds). The project disseminated knowledge of actual as opposed to rumoured outcomes of mining livelihoods, to facilitate the formulation of policies tailored to current realities.

\section{Urban poverty and property rights changes in China \\ (China)}

September 2006 - September 2008

Fulong Wu

CARDIFF UNIVERSITY, UK

The research investigated the institutional determinants of urban poverty in China, looking at the urban growth-poverty paradox from the perspectives of institutional change and the property rights and entitlement reallocations affected by those changes. It aimed to fill the gap of systematic research into the formal urban institutions that mediate the relationship between rapid urbanisation and poverty.

\section{Water-security in Ethiopia and the emotional response of pastoralists (WEEP)}

\section{(Ethiopia)}

September 2017 - March 2019

Paul Hutchings

CRANFIELD UNIVERSITY, UK

This research seeks to understand the emotional response of pastoralists to water insecurity, which is caused by pasture disputes with other land users; the changing climate, which alters resource availability; and government attempts to persuade pastoralists to diversify their farming activities. The project compares three types of habitation - those dominated by pastoralists, mixed habitations, and those where pastoralists form a minority - and explores how water use can be rewarding, stressful, or disappointing.

\section{Wellbeing and poverty pathways}

(India, Zambia)

August 2010 - April 2014

Sarah White

UNIVERSITY OF BATH, UK

This research identified pathways of wellbeing and poverty within rural communities in Zambia and India, demonstrating how poverty affects wellbeing and how different constellations of wellbeing in turn affect people's movements into, within, and out of poverty. It adopted a mixed method, cross-cultural longitudinal approach, with qualitative and quantitative data collection across a two-year interval, statistical tests to 
assess the validity and reliability of their model of wellbeing, and in-depth case studies.

\section{What development interventions work?}

\section{(Bangladesh)}

March 2008 - October 2010

Agnes Reynes Quisumbing

INTERNATIONAL FOOD POLICY RESEARCH INSTITUTE (IFPRI), USA

While government and NGOs in Bangladesh have undertaken many interventions designed to help households escape poverty, little has been known about their long-term impact. Using a new longitudinal data set spanning 12 years and more than 1,800 households, this project investigated the long-term impact of three anti-poverty interventions - microfinance, agricultural technology, and educational transfers - on several measures of wellbeing and compared their cost-effectiveness.

\section{Widening participation in higher education in} Ghana and Tanzania: developing an equity

\section{scorecard}

(Ghana, Tanzania)

September 2006 - January 2010

Louise Morley

UNIVERSITY OF SUSSEX, UK

This project investigated interventions for widening participation in one public university and one private university in Ghana and Tanzania. It explored the factors that facilitate or impede participation in higher education, and examined approaches taken by state and private providers to widen participation.
Women empowerment, social norms and domestic violence

(Egypt)

October 2016 - March 2019

Paul Collier

UNIVERSITY OF OXFORD, UK

This project explores how to design effective and efficient interventions aimed at reducing domestic violence (DV), especially among vulnerable groups in conflict-affected areas. In order to advance our understanding of DV, its causes and how interventions can better reduce it, the research examines the extent to which different factors affect the prevalence of DV, and how the interactions between the different factors drive DV and influence household cooperation and multidimensional poverty.

\section{Zero hunger - zero emissions: enabling the} debate on how to feed the world whilst mitigating climate change (Bangladesh) September 2017 - November 2018 Monika Barbara Zurek UNIVERSITY OF OXFORD, UK There is an urgent need to find means by which societies can engage in difficult debates about how to ensure food security, in a world threatened by dangerous levels of climate change. This research aims to design and test an inclusive and replicable process, based on participatory scenario methodology, to enable those debates to take place in ways that involve broad swathes of society, including people who often have least voice. 


\section{ESRC-DFID's Strategic Partnership - research evidence for policy makers and practitioners}

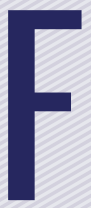

ormed in August 2005, the UK's Economic and Social Research Council (ESRC) and the Department for International Development (DFID) Strategic Partnership funds worldclass scientific research on a broad range of topics. The partnership contributes to a robust conceptual and empirical basis for development and funds the Joint Fund for Poverty Alleviation Research, the Raising Learning Outcomes in Education Systems Research Programme, and the Growth Research Programme (DEGRP).

- The Joint Fund for Poverty Alleviation Research aims to enhance the quality and impact of social science research with the goal of reducing poverty amongst the poorest countries and peoples of the world. The primary aim of the scheme is to fund scientific research with potential impact on policy and practice for poverty reduction. Since 2005 , the fund has enabled a portfolio of 172 projects $^{2}$ on issues ranging from child poverty and inequality, secure livelihoods, disability, inequality in education, health system reform, climate adaptation and much more besides. The most recent funding phase is due to complete in 2021.

Visit www.esrc.ac.uk/international-development for further information.

- The Raising Learning Outcomes in Education Systems Research Programme aims to provide policymakers and practitioners with concrete ideas on how to improve learning and understanding of how these will translate to their specific context and institutions, and to demonstrably inform relevant policy and programme decisions. The research funded through this programme focuses on how to raise learning outcomes for all by considering equity (including gender and disability) as well as quality dimensions of education. The current programme runs from January 2014 to March 2022.

Visit www.esrc.ac.uk/eddev for further information.

- The Growth Research Programme (DEGRP) focuses on issues related to economic growth in low-income countries (LICS).

Visit www.esrc.ac.uk/international-development for further information.

${ }^{2}$ According to the data available at the time of printing. 


\section{THE IMPACT INITIATIVE}

\section{For International Development Research}

This booklet provides an overview of poverty alleviation research encompassing 172 projects focused in 77 countries, and globally, which have been enabled by the UK's Economic and Social Research Council (ESRC) and the Department for International Development (DFID) Strategic Partnership.

The Impact Initiative for International Development Research seeks to connect policy makers and practitioners with the world-class social science research supported by the ESRC-DFID Strategic Partnership, maximising the uptake and impact of research from: (i) the Joint Fund for Poverty Alleviation Research, and (ii) the Raising Learning Outcomes in Education Systems Research Programme. We seek to identify synergies between these programmes and their grant holders, support them to exploit influencing and engagement opportunities, and facilitate mutual learning.

The Impact Initiative is a collaboration between the Institute of Development Studies (IDS) and the University of Cambridge's Research for Equitable Access and Learning (REAL) Centre.

Email: info@theimpactinitiative.net

Website: www.theimpactinitiative.net

Y@the_Impact_Init \#impactlessons \#policies4 